Mediterranean Journal of Humanities mjh. akdeniz. edu. tr $\mathrm{V} / 1,2015,17-42$

\title{
Yemen'in Kuzeyinde Osmanlı İdaresinin Yeniden Tesis Edilmesi ve Mekke Şerif Muavini Kıbrıslı Tevfik Paşa (1848-1851)
}

\author{
Muavin Tevfik Pasha (1848-1851) and the Re-Establishment of Ottoman \\ Authority in North Yemen
}

Durmuş AKALIN*

Öz: Osmanlı Devleti, ilk kez Mısır'ın fethinden sonra Hadım Süleyman Paşa ile Osmanlı topraklarına katılan Yemen'in elde tutulması için I. Dünya Savaşı'na kadar yoğun bir çaba harcamıştır. Ele geçirilişinden bir süre sonra Zeydilere karşı tutunamayan Osmanlı Devleti bölgeden çekilmiştir. Ne var ki 19. yüzyıl siyasi ve askeri olaylarının doğurduğu endişelerle birlikte Osmanlı Devleti Yemen'de tekrar harekete geçmek zorunda kalmıştır. Bu kapsamda Sultan Abdülmecid zamanında Tevfik Paşa'nın gerçekleştirdiği askeri harekât son derece önemlidir. Tevfik Paşa, bölgenin nazik durumu karşısında Osmanlı üst makamlarının bölgeye ehemmiyet vermesine ön ayak olmuş ve Yemen'deki Osmanlı askeri faaliyetlerinin gerçekleştirilmesinde önemli bir görev üstlenmiştir. Osmanlı Devleti'nin bölgede böyle bir teşebbüse kalkışmasında Kızıldeniz ve Arap Yarımadası'nın güvenli hale getirilmesi de etkili olmuştur. Mekke ve Medine gibi kutsal toprakların güvenliği ve Osmanlı Devleti'nin sınırları içinde yer alan Müslüman ahali arasında düzenin devam ettirilmesi bakımından da Yemen'in kontrol altına alınması gerekli görülmüştür. Bu araştırma ile Kıbrıslı Tevfik Paşa üzerinden Osmanlıların gerçekleştirdikleri askeri faaliyetler tetkik edilmeye çalışlacaktır. Hadisenin gelişmesinde Kıbrıslı Tevfik Paşa son derece önemli bir noktada olduğu için olayların gelişimi onun üzerinden ele alınacaktır. Bunun yanında meseleyi daha iyi kavrayabilmek için yer yer devrin genel siyaseti ve Osmanlı Devleti’nin bölge üzerindeki politikalarına da yer verilecektir.

Anahtar sözcükler: Osmanlı Devleti, Kıbrıslı Tevfik Paşa, 19. Yüzyı1, Yemen, Kızıldeniz

\begin{abstract}
After the conquest of Egypt, the Ottoman State had firstly through Hadim Suleiman Pasha, made an intense effort for the retention of the territory of Yemen within Ottoman territory until the outbreak of World War I. After a while, the Ottomans had withdrawn substantially from the region being unable to stand up to the Zaid. However, the Ottoman state was forced to move back into the action in the Yemen due to the concerns raised by the political and military events of the $19^{\text {th }}$ century. Within this context, the military action undertaken by Muavin Tevfik Pasha during the reign of Sultan Abdulmecid, was extremely important. Muavin Tevfik Pasha understood that the important Ottoman authorities attached importance to the region and he had taken on an important task to realise them through military operations. The reason for attempting such an undertaking was the Ottoman concern to secure the Red Sea and the Arabian Peninsula. The control of Yemen was necessary, in terms of the security of the Holy lands of the Hejaz, Mecca and Medina and the continuation of the relationship of the ruler and Muslim community within the boundaries of Ottoman territory with this duty. The military operations undertaken by Muavin Tevfik Pasha on behalf of the Ottoman state are investigated in this article and as Muavin Tevfik Pasha had a very important role in the development of these events, the article focuses on him. In addition there is included a description of the wider politics of the period and also of the policy of the Ottoman state in this region, in order to more completely understand this issue.
\end{abstract}

Keywords: The Ottoman State, Muavin Tevfik Pasha, $19^{\text {th }}$ Century, Yemen, Red Sea

\footnotetext{
* Yrd. Doç. Dr., Pamukkale Üniversitesi, Fen-Edebiyat Fakültesi, Tarih Bölümü, Denizli. dakalin@pau.edu.tr
} 
Yemen, Osmanlı Devleti topraklarına dâhil olduğu andan itibaren son derece kıymet verilen yerlerden biri olmuştur. Ancak ilk dönemlerinden itibaren bir türlü bölgede asayiş sağlanamamıştır. Bölgedeki kabilelerin durumu, yabancı devletlerin bölgedeki etkisi, ticaret, ulaşım ve değişik yerlerden gelen hacılar için burası önemli görülmüştür. Hicaz topraklarının Osmanlı sınırları içerisinde olması da Osmanlıların Yemen'le daha fazla ilgilenmelerini sağlamıştır. Ancak Osmanlı Devleti'nin Yemen'de ikinci defa bir hâkimiyet kurmasından evvel Mehmed Ali Paşa'nın kuvvetleri bir ara Aden'e kadar uzanan bir sahayı kontrolü altına almıştır. Mehmed Ali Paşa'nın bir süre sonra Mısır'a sıkıştırılmasıyla birlikte Yemen de dâhil olmak üzere Mısır askerleri birçok noktadan geri çekilmişler ve bu yerlerde Osmanlı hâkimiyeti yeniden tesis edilmeye çalışılmıştır.

Osmanlı Devleti'nin Kızıldeniz'deki etkinliği Mısır'ın alınmasıyla birlikte başlamıştır. Hint Okyanusu'ndaki hâkimiyet için yapılacak deniz mücadelelerinde kullanılmak üzere Süveyş’te, bir Süveyş Kaptanlığı kurulmuş ve ilk Süveyş Kaptanı Selman Reis olmuştur (Gencer 2001, 14). $\mathrm{Bu}$ dönemde Kızıldeniz'de ve Yemen taraflarında Avrupalı deniz güçleri etkin bir durumdaydı (Akalın 2014, 235-236). Bundan böyle Osmanlı Devleti'nin gerilediği 19. yüzyıla kadar Süveyş, Kızıldeniz'de yürütülen faaliyetler ve Yemen'e kadar uzanan Osmanlı nüfuzu için önemli bir merkez vazifesi üstlenmiştir. 19. yüzyılın başında Yemen ve Kızıldeniz'deki gelişmeleri etkileyen faktörlerden biri Mehmed Ali Paşa olmuştur. Mehmed Ali Paşa, 18 yaşında askerlik hizmetine girmiş ve bu meslekte de hemen sivrilmesini bilmiştir. Napoleon'un 1798'de Misır'1 işgali üzerine, Osmanlı Devleti buraya bir ordu göndermiş ve bu orduya Kavala'dan bir takım ücretli askerler de dâhil edilmişti. Mehmet Ali, Kavala birliklerinin komutan yardımcısı durumundaydı ve Mısır'a geldikten biraz sonra bu birliklerin komutanı oldu (Armaoğlu 1999, 194195). Misır'daki zorlu mücadeleden sonra Osmanlı Devleti, halk tarafından da sevilen Kavalalı Mehmed Ali Paşa karşısında fazla 1srarlı olmadı ve 19 Haziran 1805'te onu Mısır Valiliği'ne atadı. Mehmed Ali Paşa'nın ilk askeri başarısı, Mart 1807 tarihinde İskenderiye'yi zapt etmiş olan İngilizlere karşı oldu (Akalın-Parlaz 2010, 122). Bundan sonra Mehmed Ali Paşa çok geniş bir sahada hâkimiyet tesis etmeye başladı.

1812'de Mehmed Ali Paşa, Hicaz'da çıkan Vehhabi İsyanı'nı bastırmaya memur edildi. Oğulları İbrahim ve Tosun Paşaları Vehhabiler üzerine gönderdi. Kısa bir zamanda isyan bastırıldı. Bütün bu olaylar Mısır paşasının kuvvet derecesini gösteriyordu (Karal 1999, 127). 1833 yılında, Mısır valisi Kavalalı Mehmed Ali Paşa'nın ümerasından “Türkçe Bilmez” lakabıyla bilinen biri, Mehmed Ali Paşa'ya başkaldırdı ve Cidde'de topladığı bir miktar askerle Yemen’e saldırd. Fakat Yemen'in birkaç şehrini eline geçiren Türkçe Bilmez, orada tutunamayarak kaçtı ve yakalanarak Mısır'da idam edildi. Bu şekilde Yemen'le ilişkisi başlayan Mehmed Ali Paşa, 1835 yılında Mirliva Emin Bey komutasında kara kuvvetlerini Yemen'e doğru yolladığ gibi, küçük çaptaki bir deniz gücünü de oraya doğru harekete geçirdi. Yemen'e saldıran Misır askerleri ciddi bir direnişle karşılaşmaksızın Luhayya ve Hudeyde iskelelerini ele geçirdiler. Bunu müteakip Mehmed Ali Paşa, İbrahim Paşa komutasında yeni bir kuvvet göndererek Tihame'nin bütününü Asirlilerden aldı (Baldry 1976, 160-161; Sırma 2008, 53-55; Ahmet Raşit Paşa 2013, 155). Mısır hükümeti tarafından gönderilen kuvvetler, Yemen sahillerini istirdat etmekle beraber, Asir'de tam anlamılla muvaffak olamadılar. Dağlıların çetin müdafaası ile karşılaşan, iyi iaşe edilemeyen ve kolera gibi salgın hastalıklar ile kırılan Mısır kuvvetleri, 1837'de memleketi tahliyeye mecbur kaldılar ve daha sonra 1840 mukavelesi hükmüne uyarak, Yemen sahillerini de bırakıp gittiler (Yeşilyurt 2011, 57). Dört sene sonra, İstanbul hükümetinin gönderdiği küçük bir askerî kuvvet takriben bir asır süren hâkimiyetini müteakip terkedilen bu sahillere tekrar çıktı (Darkot 1997, 675). 
Mehmed Ali Paşa bir ara 1837'de Yemen'in Kızıldeniz sahillerinde hâkim bir duruma geçti. $\mathrm{Bu}$ ara Ebu Ariş şeyhi Şerif Hüseyin bölgede etkinliğini arttırmak için Mehmed Ali Paşa ile işbirliği yaptı. Bunun üzerine San’a İmamı, İngilizlerin kendisini koruması için Aden'e bir teklif götürdü. Şerif Hüseyin de bu dönemde Moha'daki İngiliz acentasına bazı zorluklar çıkarmaya başladı ve giriş tarifelerini \%2,25'ten \%9'a yükseltti. Bunun üzerine İngilizler İstanbul'da şikâyetçi olunca Osmanlı Devleti 1842'de Eşref Bey'i bir komisyon başında Yemen'e gönderdi (Baldry 1976, 160-161). Osmanlı Devleti bu sırada Şerif Hüseyin'e paşa unvanı verdi ve Tihame Bölgesi'nin kontrolü Şerif Hüseyin'in kesin olarak eline geçti. Bir ara Şerif Hüseyin Osmanlı Devleti'ne danışmadan Ta'iz ve İbb üzerine harekete geçtiyse de daha sonra buralardan geri çekildi (Baldry 1976, 162).

Aradan geçen bir süre sonra Mehmed Ali Paşa, (1846'dan itibaren) idari bir görevde bulunamayacak derecede hastalandı. Bunun üzerine oğlu İbrahim Paşa (1789-1848) vali tayin edildi. Ancak İbrahim Paşa'nın da valiliği uzun sürmedi. İbrahim Paşa, üç ay valilikte kaldıktan sonra öldü. Ardından valiliğe Mehmed Ali Paşa'nın torunu I. Abbas Hilmi geçti (Kızıltoprak 2010, 12). Mehmed Ali Paşa, 1849'da vefat ettiğinde, Mısır'ın nüfuzu Nil'in yukarı kısmında Faşoda'ya ve Beja memleketine, Kassala'ya Habeşistan hududunda Take'ye kadar yayılmıştı. Onun vefatı üzerine Sevakin ve Musavva da Hicaz valisinin mutlak kontrolüne verildi (Orhonlu 1996, 147). Ancak terk edilen Yemen sahillerinde henüz tam bir Osmanlı hâkimiyeti tesis edilememişti.

Yemen'de yeniden Osmanlı hâkimiyetinin tesisini arzu eden Sultan Abdülmecid, buraya 3.000 kişilik bir kuvvet gönderdi. Bu kuvvet 1849'da Hudeyde'ye çıktı. Bundan sonra Hudeyde Türklerin, Yemen'de başlıca hedefi olan San'a'yı ele geçirmek üzere, giriştikleri askeri hareketlere üs olduğu gibi, San'a ele geçinceye kadar Yemen'de kurulan mülkî teşkilatta da merkez rolünü oynadı (Darkot 1997, 580). Yemen'de Osmanlı hâkimiyetinin yeniden tesis edilmesinde Kıbrıslı Tevfik Paşa'nın önemli bir rolü oldu. Yemen hakkında Babıali'ye takdim ettiği layiha ile padişahın dikkatini çeken Kıbrıslı Tevfik Paşa (Ahmet Raşit Paşa 2013, 159) hazırlanan ordunun başında bu sefere de iştirak etti.

\section{Osmanlı Hâkimiyeti Öncesi Yemen'in Genel Durumu ve Kıbrıslı Tevfik Paşa}

Mekke Şerifi Muhammed bin Avn'in maiyyetinde muavin olarak çalışan Kıbrıslı Tevfik Paşa ile ilgili kayıtlar 30 Aralık 1846'dan itibaren kendisini göstermektedir. Bu tarihlerde Mekke Emareti muavini bulunan Mustafa Tevfik Efendi'nin 1839'da eski Misır valisi tarafindan memuriyetinin kaymakamlık rütbesine çıkarıldı̆̆ı, kendisinin devlete sadık birisi olduğu, aynı zamanda da dirayetli olduğu için muavinlik hizmetinin kendisine ihale ve ihsan buyurulduğu belirtilmektedir. Ayrıca vazifesinden ötürü mir-i miranlık rütbesi (Mülkî rütbelerden birinin adıdır. Beylerbeyi demektir. Hicri 1259 (1843) tarihine kadar mülkîye memurlarına da askeri rütbelerden olan Feriklik ve Mirliva rütbeleri tevcih olunurken o tarihten sonra askeri rütbelerin tevcihi terk edilmiş, onun yerine Ferikliğe muadil olmak üzere mir-i miran livalığa karşılık olmak üzere emirü'l- ümera rütbeleri ihdas olunmuştur. Mir-i miranlara paşa denilir. Bk. Pakalın 1993, 545) ve nişanını da almaya hak kazandığı belirtilmektedir (İ. DH. 138/7089). 13 Mart 1847 'de Maliye Nazırı'na yazılan bir yazıda, Mekke Emareti muavini Mustafa Tevfik Efendi'nin devlet hizmetinde olmasından uygun bir rütbe ve bir kıta nişan verilmesi, Mekke Emiri Şerif Muhammed bin Avn tarafından İstanbul'a yazılmıştır. Mekke şerifi, rütbe-i salise nişanın Darphane'de imal edilmesi ve Tevfik Efendi'ye verilmesine himmet buyurulmasını istemektedir (A. MKT. 70/96 (1263. 3. 25)). Bundan sonra paşa ile ilgili kayıtlar İstanbul'da bulunduğu bir sırada üstlendiği görevle ilgilidir. 
Kıbrıslı Tevfik Paşa'nın da içerisinde yer aldığı kayıtlar, Maliye Nazırı'na birkaç numara ile ifade edilen takrirlerde 3 Nisan 1847 tarihli olarak açıklanmıştır. Bu takrirlerin ilkinde Kâbe örtüsünün İstanbul'a gönderilmesi memuriyetiyle gelmiş olan Mekke Emareti muavini Tevfik Paşa'ya, şerif hazretlerinin isteğiyle Cidde hazinesinden 30.000 kuruş harcırah verilmiştir. Bu beyanla gerekenlerin yapılması Cidde Valisi Şerif Paşa hazretleri tarafından tahriratla belirtilmiş ve ihtiyaç duyulan meblağın eyaletin mesarif defterine dâhil edilmesi istenmiştir (İ. DH. 170/9031).

30 Haziran 1847'de Mekke Emiri Muhammed bin Avn'in maiyyetinde bulunan Mekke Emareti muavini Mustafa Tevfik Efendi, Yemen meselesinde iş görecek olduğundan padişahın da bilgisi dâhilinde kendisine rütbe tevcih edilmesi tekrar gündeme gelmiştir (A. DVN. 23/34 (1263. 3. 16)). Aynı gün tarihli yine başka bir belgede Mekke muavini Mustafa Tevfik Efendi'nin daha önce kaymakamlık rütbesiyle memur tayin kılındığı belirtilerek, dirayetli ve devlete faydalı olduğundan bu rütbenin üstünde olan mir-i miranlık derecesine denk gelen bir rütbe tevcihiyle nişan verilmesi ve mir-i miranlık rütbesi uygun görülerek izin istenmiştir. $\mathrm{Bu}$ isteğe verilen cevapta rütbe-i salise tevcihiyle rütbesine uygun bir kıta nişan verilmesinin yerinde olduğu belirtilmiştir (İ. DH. 138/7089). Yine konuyla ilgili, 15 Ağustos 1847 'de ise Maliye Nazırı'na yazılan bir yazıda, Mekke Emareti muavini Mustafa Tevfik Efendi'ye uygun bir rütbe ile bir kıta nişan verilmesi hususunun, Mekke Emiri Şerif Muhammed bin Avn tarafından İstanbul'a yazıldığg tekrar edilmiştir (A. MKT. 93/15 (1263. 9. 3)); A. MKT. MHM. 2/66 (1263. 8. 9)). 8 Eylül 1847 'de İstanbul'a gönderilen kayıtlarda ise, Necid ve Yemen meselelerinin Mekke emirinin gayretleri ile halledildiği ifade edilmiştir. Konuyla ilgili meselelere hâkim ve sadık bir kişi gönderilirse bu işlerin halledileceği üzerinde durulmuştur. Bu noktada, emirin Mekke'de başmuavini olan Tevfik Efendi'nin Hicaz taraflarına dair bilgi sahibi olmasından onun bu memuriyete getirilmesinin yerinde olacağı açıklanmaktadır (HR. MKT. 18/55 (1263. N. 27)).

Yemen üzerine yapılacak işlere dair Tevfik Efendi'nin uygun isim olacağı şeklinde yazışmalar devam ederken, şerife yazılan bir yazıda konuyla ilgili ayrıntılı bir şekilde durum değerlendirmesi yapılmıştır. Buna göre, Şerif Hüseyin'in San'a İmamı'yla arasındaki hadisenin Yemen meselesi hakkında daha önce varılan mütalaa ve kararı değiştirdiği ifade edilmiştir. Şerif Hüseyin, İmam'ın esaretine tutulmuş olduğundan Yemen mevzusunun düzeltilmesi için alınacak mahalli tedbirler, gerekli olan akçe ve asker durumu Eşref Bey'in (Eşref Bey, Yemen meselesinin çözümü için bu sırada Osmanlı Devleti'nin gönderdiği hususi bir memurdur. Bk. Ahmet Raşit Paşa 2013, 160) gelmesiyle Cidde Valisi’nden birkaç kıta tahriratın alındığı beyan edilmiştir. Bu konuda padişah da meseleye özel bir önem atfettiğinden ve Kıbrıslı Tevfik Paşa'nın hazırlayıp sunduğu layiha da bütün vükela tarafından görüşüldüğünden kendisinin konuya vakıf oluşu takdir edilmektedir. Bunun için bir memur verilmiş ve İngilizlerin dahi Aden tarafindaki konumları göz önüne alınarak konunun dış baskıya maruz kalmadan çözülmesi istenmiştir (A. MKT. 160/51 (1264)). Bu sırada İngilizler de Aden'de daha etkin bir duruma geçmişlerdi. Aden'deki İngilizlerin varlığı Kaptan Haines'in 1839'daki faaliyetleri ile başlamıştı. Sultan Muhsin ve bazı Arap kabile liderleri 1839 ve 1840 'ta birkaç defa İngilizleri Aden'den çıkarmak için çarpışmışlarsa da bunu yapamamışlardı (Akalın 2014, 368-369).

Osmanlı Devleti ilk etapta Yemen meselesinin halli için bütün kaynaklarını seferber etmeye çalışmıştır. Yemen meselesi için 5.000 kese akçe toplanarak Cidde Defterdarı Sadi Efendi'ye gönderilmiştir. Bu paranın harcanmayan kısmı kalırsa onun da Hicaz'a bırakılması kararlaştırılmıştır. Yemen'e asker gönderilerek durum kontrol altına alınacak olsa da gidecek askerlerin oranın havası ve suyuna alışamayacaklarından talebin belki ertelenebileceği belirtilmiştir. Bölgeye aşina olanlardan seçilecek adamların istihdam edilmesinde ise birçok fayda olacağı 
ifade edilmiştir. $\mathrm{Bu}$ noktada Mekke'de yeterli miktarda başıbozuk askeri olmadığından Mekke'nin savunmasına zarar getirmeyecek kısmının bırakılarak geri kalan kısmının nizamiye askerlerine dâhil olmaları istenmiştir. Bunun yanında başka bir çözüm olarak limanlara ve başka yerlerde istihdam olunmak üzere Hicaz'dan götürülecek başıbozuk askerinden başka Mısır Valisi eliyle Mısır ve İskenderiye'den 800-1.000 civarında asker toplanabileceği de belirtilmiştir. Askerlerin toplanmasından Hicaz'a varmalarına kadar geçen süredeki masrafları Yemen tahsisatından başka bir şekilde ödenmesi kararlaştırılmıştır. Cidde eyaletinde mevcut iki adet şotiyeden (Kızıldeniz'in birçok limanında kullanılan küçük gemilere verilen isimdir) başka mühimmat ve diğer taşıma işlerinde kullanılmak üzere ve muhabere sağlamak amacıyla Mısır'ın Kızıldeniz'de olan gemilerinden 3 büyük ve 2 küçük gemi ile 1 adet vapur temin etmesi istenmiştir (A. MKT. 160/51 (1264)).

Denizden gidecek başıbozuk askerleri kumanda etmek, emirleri yerine getirmek üzere ve bölgenin durumuna hâkim birinin kendisine mir-i miranlık veya emirü’l- ümeralık rütbeleri verilerek gerekli nişan ve fermanların gönderilmesinin lazım geldiği ifade edilmiştir. O taraflarda bu konuya pek de hâkim bir zat bulunmasa da Kıbrıslı Tevfik Paşa'nın duruma hâkimiyetinden dolayı gerek kendisinin gerekse de başka birinin bu işi yapabileceği ve bunun için de her iki duruma uygun nişanların hazırlanması istenmiştir. Bir de Yemen tarafının maliye ve zaptiyesine tayin olunacak kişiden başka ahali ve Araplar için "Şerif” (Yükselmek, tebarüz etmek manasında olan bu asil yüksek kelimesi şanlı şöhretli atalara sahip olmak dolayısıyle üstün bir mevki talebine hakkı olan hür kimseyi ifade eder. Bk. Arendonk 1997, 435) namıla birinin atanması gerekli görülür ise bunun için oyalanılmayarak gereğinin yapılması istenmiştir. Kendisine ne kadar maaş verilmesi gerekirse verilmesi de söylenmiştir. Bunun yanında kundakları tam olarak ve topçularıyla birlikte bir buçuk çapında 2 kıta top gönderilmesi yine maaşları Cidde Hazinesi'nden verilmek üzere 1 adet doktor ve 2 adet yardımcısının da gönderilmesi gerekli görülmüştür. Hüseyin Paşa tarafından Asir kabilesine verilmekte olan 18.000 riyal, bu kabilenin zapt edilmesi ve kontrolün sağlanması bakımından gerekli görülerek bu paranın o taraftan toplanacak gelirlerden karşılanması istenmiştir. Şimdiye kadar verilmiş olan paradan dolayı Cidde Valisi'nin bu konuya dikkat etmesi ve toplanan gelirler için yine kendi aralarında görüşerek bir uygun yol belirlemeleri istenmiştir. Bu vergilerin sorun çıkarılmadan toplanması ve nakledilmesi de kendilerine bırakılmıştır. Vergilerin toplanması işinde gayret gösterenler ve yararlı çalışmaları olanlar varsa belirlenmesi ve kendilerine nişanlar verilmesi konusunda haber verilmiştir. Yemen'in mevcut durumu Osmanlı Devleti için önemli görüldügünden San'a İmamı ve Şerif Hüseyin arasındaki sorunun devlet adına hayırla çözülmesi gerektiği vurgulanmıştır. San'a İmamı'na galebe olunursa Yemen'e bir şerif tayin edilebileceği ancak şimdiki imam Osmanlı Devleti'ne bağlığını kabul ederse onun, olmazsa bir başkasının o da olmazsa başka münasip birisinin imam olarak atanabileceği valiye bildirilmiştir. Adı geçen akçe ve topların defterdar paşaya teslim edilmesi ve yine doktor ile yardımcılarına verilecek nişanların gönderilmesi ve valiyle ittifak halinde bu işlerin yapılmasına dair bir yazı gönderilmiştir (A. MKT. 160/51 (1264)).

Yaşanan bu gelişmeler yanında Mekke Şerif muavini Kıbrıslı Tevfik Paşa'ya bir yazı gönderilerek, şerifin kitabet hizmetinde bulunan Mehmed Salim Efendi'ye nişan verilmesi ve lüzumu halinde kullanılmak üzere 3 adet çadırın gönderilmesine dair onay verildiği bildirilmiştir (A. MKT. 160/28 (1264)). Böylece yapılacak askeri faaliyetlerle ilgili hazırlıklar başlamıştır. Yine bu kapsamda Kıbrıslı Tevfik Paşa'ya gönderilen haberlerde, Yemen işinde kullanılmak üzere ve Hicaz'dan temin edilecek başıbozuk askeri ve Mısır'dan 500'den fazla olacak başıbozuk askerlerinin ne şekilde Hicaz'a sevk edileceğine dair yazılar da padişaha sunulmuştur (A. MKT. 157/52 (1264. 12. 4)). Bu gelişmeler sırasında Mekke Şerifi Muhammed bin Avn'in oğlu 
Abdullah da Yemen'de yapılacak hazırlıklar için devletin elde tuttuğu isimlerden biri olmuştur. Bu noktada 6 Ocak 1848 'de yapılan yazışmalar gereği bazı rütbe ve nişan tevcihleri yapılmıştır. Uhdesine mir-i miranlık rütbesi ve paşalık unvanı verilen Şerif Abdullah Paşa'ya ve babası Şerif Muhammed bin Avn tarafina bütün Mekke ahalisinin ve hacıların emniyeti ve selametle gelip gidebilmeleri için mir-i miranlık rütbesi ve paşalık unvanı verilmiştir. Aynı şekilde mir-i miranlık rütbesi ve paşalık ünvanı verilmiş Şerif Ali Paşa'nın, babası Mekke Emiri Şerif Muhammed bin Avn maiyyetinde bulunması istenmiştir. Benzer şekilde de Mekke Emareti başmuavini Kıbrıslı Tevfik Paşa'nın mir-i miranlık ve paşalık rütbeleri kendisine tevcih edilmiştir (A. DVN. 35/43 (1264. 1. 29)).

Yemen meselesi ile ilgili görüşme ve yazışmalar devam ederken 1 Şubat 1848 'de, Kâbe örtüsünün ulaştırılması işine memur Mekke başmuavini Kıbrıslı Tevfik Efendi ve Cidde Hazinedarı Hacı Ahmed Efendi Mekke Emiri ve Cidde Valisi taraflarından ve Yemen meselesine memur Eşref Bey canibinden birtakım tahriratlar İstanbul'a ulaşmıştır. Bu tahriratlar özetlenerek Meclis-i Umumi akabinde toplanan Meclis-i Hass'da okunmuştur. Eşref Bey, Cidde'den Hudeyde'ye giderek Şerif Hüseyin ile mülakatından sonra şerifin Yemen Emareti'nin evladına da geçmek üzere kendisine verilmesini, bunun yanında kendisine bir kıta nişan ve her sene birer ferace (Çarşaftan evvel kadıların tesettür için giydiği üstlügün adıdır. İlmiye ricalinin resmi günlerde giydikleri sırma işlemeli üstlüğe de ferace denilirdi. Biniş dahi denilen bu feracenin kolları çok boldu. Çuhadan yapılırdı. İlmiyenin ferace giymeleri Hicri 1264 (1848) senesinde rütbelerde yapılan tadilat ile başlamış, Osmanlı saltanatının sonuna kadar devam etmiştir. Bk. Pakalın 1993, 601-602) verilmesini istemiştir. Yemen iskelelerine memur tayin olunmasına izin verilmesi beyanıyla bu sırada kendisine nişan verilecek olursa bu nişanın daha önce şeyhe verilen İstabl-i Amire Müdürlüğü'nden yukarıda olması ve feracenin dahi Mekke Şerifi'ne gönderilenden farklı olmak üzere kırmızı çuhadan yapılması ve gönderilmesi istenmiştir. Fakat vali, iskelelere gönderilmesine karar verilen kâtiplerin gönderilmesi maddesine pek taraftar görünmemiştir (İ. MSM. 63/1810 (1264 S. 25)).

İstanbul'a gönderilen yazılardan Şerif Hüseyin'in Mekke Şerif'i Muhammed bin Avn'in oğlu gibi şerifliğin oğluna da geçmesi niyetinde olduğu anlaşılmıştır. Bunun yanında emirin Eşref Bey'i beklemeyerek Necid Şeyhi Fazıl'ın üzerine varıp oraya yıllık 10.000 frank vergi koyarak ordusunun masrafları için 15.000 frank aldığı öğrenilmiştir. Bu konuda gelen yazıların da bu bilgiyi tasdik ettiği tekrar hatırlatılmıştır. Ayrıca Şerif Hüseyin ile İngilizler arasında daha önce yaşanan bir sorundan dolayı İngilizler şerife karşı tavır takınmışlarsa da şerifin oradan kaldırılması konusunda bir istekte bulunmadıkları bildirilmiştir. Bu durum üzerine hemen yeterli kuvvet ile Yemen'e gidilerek duruma bakılacağı ifade edilmiştir. Şerif Hüseyin'in emaretin kendisinden sonra oğluna geçmesi konusundaki isteğinin de güzel bir şekilde savuşturulması istenmiştir (İ. MSM. 63/1810 (1264 S. 25)).

Bundan başka daha önce verilmiş olan emaret nişanı ortası altınlı nişanlardan olsa da Mirü'l-hac ve Cidde Valisi gibi paşaların nişanlarından olmadığı belirtilmiştir. Bundan dolayı nişanının değiştirilmesi eğer değiştirilemezse eski nişanının büyük oğluna verilmesi, oğluna verilen nişanın da emirin küçük oğluna verilmesi teklif olunmuştur. Eğer bunlar mümkün olmazsa emir ve Cidde Valisi'ne bir kıta nişan daha verilmesi ifade edilmiştir. Bu sırada o tarafların kontrol altına girmekte olduğu, Halife'nin adının anılması, bir miktar vergi tahsisi ve Osmanlı Devleti'ne bir miktar kuvvet verdiği beyan edilmiştir. Şerif Hüseyin'in istenenleri yapmasıyla İngilizler de şerif adına yeni bir iddiada bulunmamışlardır. Eğer böyle bir iddia tekrar olursa gereğinin yapılması ancak İngilizler tarafından bir şikâyet olmadığından konunun artık mesele edilmemesi tavsiye edilmiştir. Ancak konunun dâhili kısmının düşünülmesi icap 
edeceğinden Şerif Hüseyin'in bağlılı̆̆ının pek de istenilen derecede olmaması sebebiyle daha öncelerde dahi cereyan eden müzakereler gereği şerifin oradan kaldırılıp yerine bir vali tayin kılınması veya kendisi, durumu şimdilerde toparladığından kendisine dokunulmayıp bu şekilde kalması uygun görülmüştür. Alınacak tedbirlere ve şerifin ileride göstereceği tavra göre hareket edileceği beyan edilmiştir. Yine şerifin istediği nişan münasip görünmüş fakat öylece bir nişan gönderilmektense şerife bir münasip rütbe dahi verilmesi yerinde görülmüştür. Münasip bir rütbe verilmesinin yabancılar nazarında da faydalarının olacağı üzerinde durulmuştur. Mesela kendisine bir paşalık verilse bundan ziyadesiyle memnun kalacağı açıklanmıştır. Şerife bu noktada mir-i miranlık tevcih olunması gündeme gelse de eğer böyle bir tevcih olursa Mekke Emiri ile aynı rütbeye ulaşmış olacaktır. Mekke Emiri bundan rahatsız olmazsa da bir kere durumun gizli bir şekilde muavine sorulması istenmiştir (İ. MSM. 63/1810 (1264 S. 25)).

Şerif, Yemen'de istediği gibi harekete muktedir olduğundan hasılat ve varidatı layıkıyla meydana çıkartmayarak diğer taraftan dahi ziyadesiyle masraf çıkartmasıyla belki devletten fazladan akçe talep edecektir. Bu durumu çözmek üzere harekete geçilse devletin sarf etmekte olduğu mesaisi gelir elde etmekten ibaret gibi anlaşılacaktır. Asıl maksat devletin hukukunun yerleşmesi ve Hicaz taraflarının asayişi olduğundan, şimdilik gümrükler için kâtipler gönderilmesinden sarfınazar olunacaktır. Ancak adı geçen Eşref Bey orada iken Yemen Sahili'ne gelen İngiltere beylik gemisi kaptanıyla mülakatında şerifin garip muamele ve hareketi ve daha önce İngiltere ile vuku bulan sorunlarına nazaran bir gün oraca patırtı çıkarmasının mümkün olduğu ifade edilmektedir. Bunun önüne geçmek için Mekke Emareti bünyesinde bulunduğu şekliyle hem ora ahvalini hem de Arapça bilen Cidde'deki memurlar arasından bir memurun muavin namıyla şerifin maiyetine gönderilmesi uygun görülmüştür. Bu muavin oraya gidince her işteki durumu bu tarafa bildirecektir. Ayrıca bu taraftan para istemeyip şerifi gelirlerini arttırma yoluna sevk etmesini ve bir defter tutarak hazineye göndermesi maddelerini ele almasının yerinde olacağ 1 ifade edilmiştir. Şimdilik bu tedbirler yeterli görünüp hemen bu şekilde icra edilmesi istenmiştir. Nişan ve rütbe ile ferace için ise hazırlıklar yapılarak bunların Eşref Bey tarafından yeniden nasihatte bulunularak verilmesine karar verilmiştir. Şerifin istediği varidat maddesi sorunlu olup Mekke Emareti hakkında ise hiç caiz olamayacağından şerifin bu isteği bazı uygun kelimeler ile savuşturulup duruma bakılacaktır. Emir'e yazılacak yazılarda ise durum ifade edilip padişah nazarında değerinin arttığı ve evlatları için de aynı iyi niyetin devam etmekte olduğu söylenecektir (İ. MSM. 63/1810 (1264 S. 25)).

Yukarıdaki yazışmalardan da görüldügü üzere Osmanlı Devleti Yemen'de kontrolü sağlamadan önce bir otorite boşluğu vardır. Bu boşluk Ebu Ariş Şeyhi Şerif Hüseyin tarafından doldurulmuştur. Ancak Şerif Hüseyin'in uygulamalarında pek çok yanlışlıklar olduğu İngiltere ile arasının iyi olmadığı ve Osmanlı Devleti'nden daha üst rütbe ve nişan almak peşinde koştuğu dikkati çekmiştir. Üstelik Yemen'in gelirlerinin harcamalarına yetmemesi de Osmanlı Devleti'ni rahatsız eden durumlardan biri olmuştur. Bu sıkıntılara rağmen Osmanlı Devleti'nin yine de Şerif Hüseyin'le bir gerginlik yaşamadan işleri çözme yönünde bir gayreti olmuştur.

Bu dönemde Kıbrıslı Tevfik Paşa, İstanbul'a gelmiş ve yanında bazı hediyeler getirmiştir. Hediyeler arasında Cidde Hazinedarı tarafindan bir miktar amber gönderilmiştir. Bunun yanında Sadaret makamına, 1 şal, 2 çetari, 2 kezi, 1 yelpaze, 1 abez parça, 2 abani; Reis Paşa'ya, 1 şal, 3 çetari, 1 kezi, 2 abani, bir miktar ovud, 1 yelpaze gönderilmiştir. Müsteşar Bey’e, 1 sevayı, 1 çetari, 1 kezi, 3 abani, 1 sineklik verilmiştir (İ. MSM. 63/1811 (1264)). Tevfik Paşa'nın getirdiği hediyeler kabul edildikten sonra kendisine de bir karş1lı verilmesi uygun görülmüştür. Tevfik Paşa'nın hediyeleri Hicaz hediyeleri olduğundan ve reddedilmesi yakışık almayacağından hem kendisine hem de Cidde Hazinedarı'na yadigâr kılıflı bazı münasip şeylerin verilmesi uygun gö- 
rülmüştür. Adı geçen hediyelerin alınması uygun görülse de yine padişahın onayına sunulmuştur. Alınan cevap gereğince de hediyelerin alınmasında bir sakınca görülmemiştir (İ. MSM. 63/1811 (1264)). 31 Mart 1848'de de daha önce belirtildiği üzere Mekke Emiri Şerif hazretleriyle mahdumlarına ve Yemen Valisi Şerif Hüseyin Paşa ve Kıbrıslı Tevfik Paşa ile Cidde Hazinedarı Kapıbaşı Ahmed Ağa'ya lazım gelen altı kıta nişan darphaneden imal ettirilerek gönderilmiştir. Ancak kesin emir ve ferman padişaha bırakılmıştır. Kıbrıslı Tevfik Paşa ve Ahmed Ağa burada bulunduklarından emsalleri üzere nişanlarının verilerek diğerleri paşaya teslimen şerife gönderileceği belirtilmiştir. 29 Mart 1848'de sunulan bu teklife 31 Mart 1848'de olumlu cevap verilmiştir (İ. MSM. 63/1813 (1264. R. 25)).

6 Nisan 1848'de Süveyş’ten Hicaz tarafina zahire nakleden bazı gemilerin asker gönderilmesi esnasında ihtiyaçtan dolayı Cidde'ye gönderilmesi hususunda emir verilmiştir (A. MKT. MHM. 7/22 (1264. 12. 2)). Böylece hazırlıklar yavaş yavaş başlamıştır. 7 Nisan 1848'de ise Yemen meselesine dair eski Cidde Valisi ile Ferik Mahmud Paşa ile müştereken gönderilen yazılara padişahın da isteğiyle bu meselenin bir an önce çözülmesi yolunda cevaplar verilmiştir (A. MKT. 157/47 (1264. 12. 3)). 11 Nisan 1848'de bu defa Mekke Emiri başmuavini Kıbrıslı Tevfik Paşa tarafından kaleme alınan hususların bir bendinde yer alan bazı ifadeler üzerine yazı Meclis-i Vâlâ'ya gönderilmiştir. Buradan da padişaha aynen gönderilmesine karar verilmiştir. Ferik Mahmud Paşa'nın çağırılması hakkındaki tasavvur üzerine padişah da bunu uygun görerek Mahmud Paşa'nın İstanbul'a çağırılması ve oradaki askerin şimdilik miralay kumandasıyla idaresinin mümkün olduğunu belirtmiştir. Tasavvur daha sonra Seraskeriye'ye intikal ettirilmiştir. Seraskerlik makamı ordunun bir kısmının Hicaz'da bulunacağından ve şimdiki mevcudun ileride arttırılacak olmasından mevcut durumun hassasiyetini ortaya koymuştur. Ancak Mahmud Paşa'nın orada kalmasında devletçe bir mahzur göründüğünden ve şimdilik o havalideki askerin bir miralay nezaretiyle idare olabileceği Babıali tarafından belirtilmişken Mahmud Paşa'nın Cidde'de olmasının mümkün olabileceği görüşü beyan edilmiştir (İ. MMS. 15/320 (1264. Ca. 7)). Ferik Mahmud Paşa'nın Yemen üzerindeki etkisinden en çok Şerif Hüseyin rahatsız olmuştur. İkisinin geçinemeyecek oluşunun Osmanlı Devleti'nin bölgedeki durumuna zarar vereceği endişesi görevinden alınmasını gündeme getirmiştir.

Ferik Mahmud Paşa'nın İstanbul'a çağırılacak olması mevzusu epey bir görüşmeye sebep olmuştur. 29 Nisan 1848'de Seraskerlik makamı, Ferik Mahmud Paşa'nın İstanbul'a çağırılması mevzusunun Cidde Valisi'nin gönderdiği bir yazıda yer aldığııı bunun dışında Meclis-i Vâlâ'nın yazısında böyle bir ifadenin yer almadığını düşünmektedir. Ferik Mahmud Paşa'nın İstanbul'a gelmesinde bir fayda olmadığı ve ayrıca bunun epey bir masrafa neden olacağını söylemektedir. Üstelik paşa epey zamandır orada olduğundan oranın havasına ve ahvaline de vakıftır. Bu yüzden Cidde'de kalmasının daha uygun olacağı görüşü tekrar edilmiştir. Ancak İstanbul'a gelmesi veya Cidde'de kalmasından hangisi padişah tarafindan uygun görülürse onun yapılmasına karar verilmiştir (İ. MMS. 15/320 (1264. Ca. 7)). Konuyla ilgili aynı gün yapılan başka bir yazışmada da durum gündeme gelmiştir. Buna göre, daha önce Hicaz tarafına gönderilmiş olan 3 tabur nizamiye askerine dair Mekke Emareti başmuavini Tevfik Paşa tarafindan takdim olunan yazının bir bendinde ifade edilen hususların Dâr-1 Şûrâ-yı Askerîye ve Meclis-i Vâlâ'ya havale edildiği ve orada kabul edilerek padişaha sunulduğu belirtilmiştir. Bu yazıda da Ferik Mahmud Paşa'nın İstanbul'a çağırılması gündeme gelmişken Seraskerliğin belirttiği hususlardan dolayı Irak ve Hicaz Orduları'nın tertibi ve teşkili yapılmakta olduğundan, oradaki kuvvetlerin miktarının arttırılacak olmasından ve Hicaz'daki askerlerin de sayısı arttırılacağından Mahmud Paşa gibi bir büyük paşanın orada kalması uygun görülmüştür. Eğer ki paşanın yerine bir başkası atanacaksa da kendisinin orada kalarak yerine başka birisinin gönderilmesinde fayda olacağı Seraskerlik makamı ile yapılan görüşmelerden sonra ortaya çıkmıştır (İ. MMS. 15/320 (1264. Ca. 7)). 


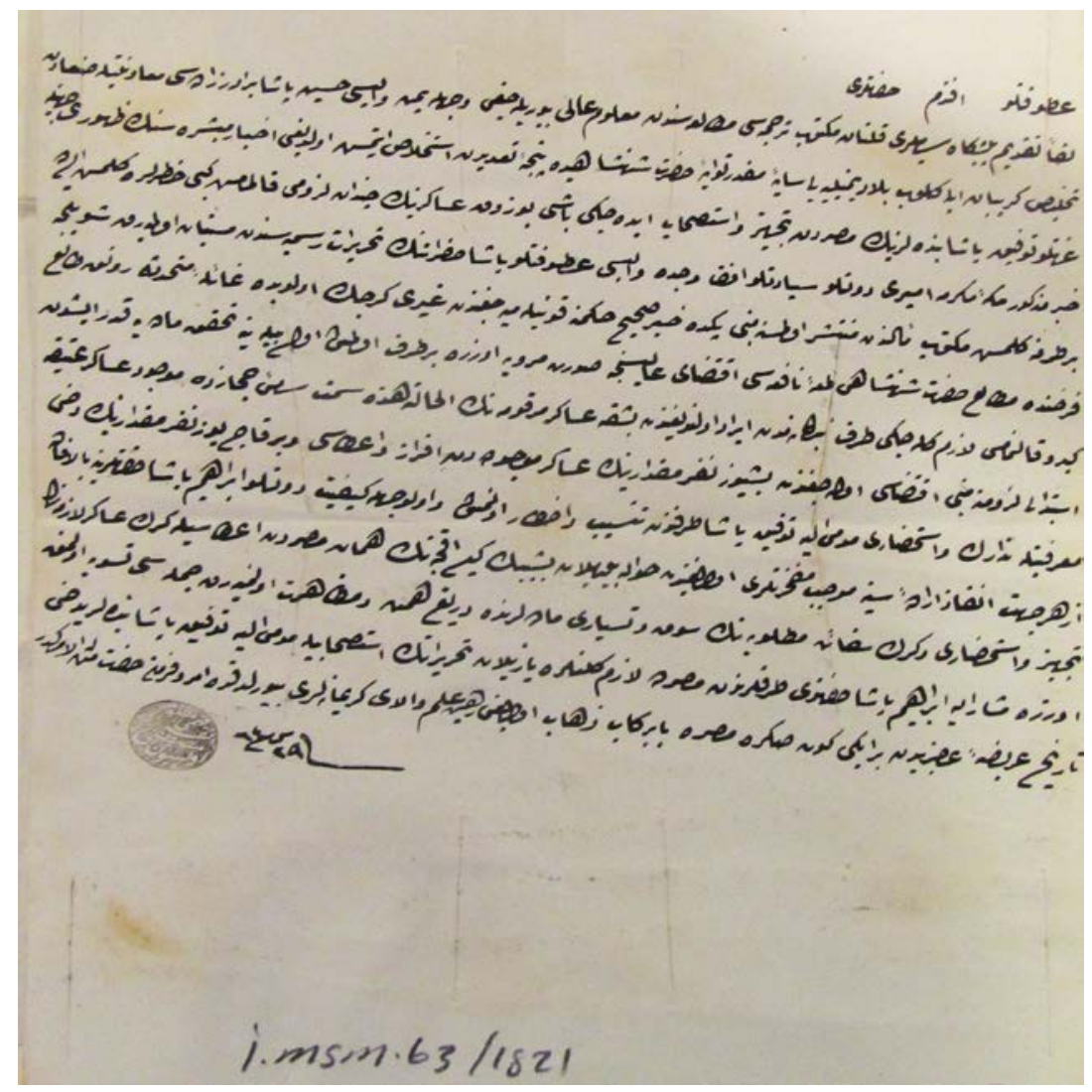

Fig. 1. Kıbrıslı Tevfik Paşa'nın Gönderdiği Yazılardan Birisi (İ. MMS. 63/1821 (1264. N. 20))

\section{2. Şerif Hüseyin ile Muhammed bin Yahya Arasında Muharebe ve Kıbrıslı Tevfik Paşa}

Kıbrıslı Tevfik Paşa'nın durumu netleşmek üzereyken Yemen'de işler karışmaya başlamıştır. Bu noktada, 9 Mayıs 1848'de San'a İmamı Muhammed bin Yahya etrafina biraz asker toplayarak Yemen Valisi Şerif Hüseyin Paşa'nın üzerine hücum ile aralarında muharebe olmuştur. Paşa'nın yanında olan askerler öbür tarafa geçmiş, kardeşi yaralandığı halde kendisi de esir düşmüştür. Eyalet, İmam'ın istilasına girmiş olduğu havadisiyle çalkalanırken Yemen meselesi memuru Eşref Bey'in İstanbul'a gelmek üzere olduğu haberi bildirmiştir. Bu gelişmeleri müteakiben Eşref Bey dahi İstanbul'a gelerek Mekke Emiri Şerif hazretleriyle, Cidde Valisi Şerif Paşa ve Hicaz Kuvvetleri Kumandanı Ferik Mahmud Paşa'nın mevcut durum ve Yemen taraflarının ahvalini içeren kâğıtları ile Mısır Valisi tarafından gönderilen bir kıta şukkayı da getirmiştir. Cümlesi özetlenip padişaha iki kıta halinde sunulmuştur. Tahrirat ve iradenin özetinden meselenin çözülmesi, Yemen'in idare altına alınması için mevcut askerlerin sayısının arttırılması bunun için de Arabistan Ordusu'ndan bir tabur askerin gönderilmesine karar verildiği belirtilmiştir. Cidde hazinesinin para sıkıntısı içinde olmasından, asker ve akçenin arttırılması gerekliliğinden ve bunlarla beraber Şerif Hüseyin'in idarece hareketlerinin yolunda olmadığından bahsedilmiştir. Bunun yanında maliyece çekilen sıkıntının Hicaz'ın gelirlerinin azlığından değil belki israf edilmekte olduğundan ileri geldiği beyan edilmiştir (İ. MSM. 63/1815 (1264. C. 5)).

Osmanlı Devleti için Hicaz taraflarının muhafazasının önemli olduğu ortadadır. Muhafazaya daima dikkat edilmesi gerekli olduğundan asayişe zarar gelmesinin kabul edilir olmadığı görüşü ağır basmıştır. Her hal ve durumda oradaki hadise, Osmanlı Devleti'ni de etkileyecek olduğundan hemen tedbir alınması gerekmektedir. Bunun için durumun Meclis-i Vâlâ'ya havalesiyle 
asker ve akçe talepleri üzerine durumun halledilmesi için Serasker ve Maliye Nezareti'yle muhabere edilerek ne suretle karar alınır ise yapılması istenmiştir. Eşref Bey'in ifadesine nazaran valinin artık orada kalmasının uygun olamayacağı belirtilmiştir. Cidde Eyaleti ise Hicaz taraflarının merkez hükümeti olarak gerek daimi idaresi ve son hadise üzerine alınacak tedbirlerin uygulanması için nice akçe gönderildiği halde israf edilerek bu işe sekte vurulmasına cevaz verilmeyeceği tekrar vurgulanmıştır. Bu cihetle maliye idaresinin düzenlenmesi, bunların dahi vükela arasında müzakere olunarak kararın bildirilmesi istenmiştir. Reis Paşa, Hariciye Nazırı, Müsteşar Beyefendi ile benzer minvalde görüşmeler olmuştur. Bu hususa dair Serasker Paşa'ya tezkereyle gelip Babıali’ye gönderilen şukkasıyla Mekke Emiri başmuavini Kıbrıslı Tevfik Paşa'nın Hicaz taraflarına dair bir kıta layihası padişaha sunulmak ve Meclis-i Vâlâ'ya verilmek üzere arz edilmiştir (3 Mayıs 1848). Sadaret tezkeresiyle birlikte bahsi geçen tahrirat özeti, takrirler, adı geçen şukka, tezkereler ve layiha padişaha sunulmuştur. Her yerin asayişi sağlanmaya çalışı1ır iken Hicaz taraflarının muhafazasının sıkıntıda olmasına teessüf edildiği bu nedenle acilen tedbirlerin alınması için Meclis-i Vâlâ'ya havalesiyle asker ve akçe hakkındaki talebin Seraskeriye ve Maliye Nezareti'ne bildirilmesi istenmiştir. Şerif Hüseyin'in artık orada kalamayacağını son hadise dahi tekrar göstermiştir. Yine benzer şekilde yukarıda belirtilen hususlara dair gerekli tedbirlerin alınması istenmiştir (İ. MSM. 63/1815 (1264. C. 5)).

Konuyla ilgili bir başka yazışmada ise Yemen üzerine olan tahkikat ve son durum ifade edilmiştir. Bu yazışmaya göre, Yemen taraflarının Şerif Hüseyin nezdinden Ta'iz ve San’a İmamı zaptına ne suretle girdiği takrirde anlatılmıştır. Firar ederek Cidde'ye gelmiş olan Hudeyde gümrükçüsü Hacı Yusuf Ağa dirayetli ve devlete bağlı olduğundan birçok kere kendisiyle mülakat olunmuştur. Bu görüşmelerden sonra Yemen taraflarının durumunun düzeltilmesine girişilmiştir. Şöyle ki Osmanlı Devleti tarafından 4.000-5.000 kese akçe harcandığı ve bu taraftan bir muhasip gönderildiği halde Hicaz tarafinda bulunan başıbozuk askeri ve üç tabur nizamiye askerini takviye için bir tabur dahi ilave edilerek bir alaya çıarılması düşünülmüştür. Bunun yeterli olacağı ve Osmanlı Devleti tarafından bir kişinin Yemen Valisi tayin edilmesi uygun görülmüştür. Vali olacak kişinin Mekke Emiri Şerif hazretlerinin memuriyetinde olacağ ve bundan başka tedbire gerek kalmayacağ 1 beyan edilmiştir. Yine Yusuf Ağa bizzat memur olacak isim ile gideceğini beyan etmiştir. Yusuf Ağa, bu kadar asker ve akçe ile Yemen'in feth ve zapt edilmesinin mümkün olduğunu ifade etmiştir. Tihame tabir olunan mahale başıbozuk ve nizamdan toplam 3.000 miktarında asker ikame ettirildiği surette askerlerin senelik masrafının 18.000 keseyi bulacağı beyan edilmiştir (İ. MSM. 63/1815 (1264. C. 5)).

Yemen üzerine hazırlıklar devam ederken Asirlilerin Tihame adlı bölge üzerine hücum etme ihtimalleri de tehlikeli bir durum yaratmıştır. Osmanlı Devleti'nin bu bölgedeki durumun nazikliğine bir kat daha zarar verecek böyle bir girişime müsaadesi olmayacaktır. Bundan dolayı gerekli tedbirleri alma yoluna gitmiştir. Konuyu bu şekilde gündeme getiren ise Aid bin Meri adlı Asir bölgesinden bir kişinin Mekke Emiri’ne bir kıta yazı göndererek çevre kabilelerin kendileri üzerine saldırılarına karşılık vermek istemesi olmuştur. Aid bin Meri adı geçenlerin ya terbiye edilmesini ya da bu işin kendisine havale edilmesini istemiştir (İ. MSM. 63/1815 (1264. C. 5)).

Kendisine bu konuda ruhsat verilmesi mümkün olmadığından Mekke Şerifi, Asir’e gitmeye karar vermiştir. Ancak Cidde hazinesi yeterli olmadığından bu gidişi sıkıntıya girmiştir. Bunun yanında şerifin hazine konusunda ifadeleri, Hicaz tarafında bulunan nizamiye askerinin dört aylık maaşlarının ödenememesinden dolayı zor durumda oldukları Hicaz'a memur Ferik Mahmud Paşa ve askeri ümera tarafından da tasdik edilmiştir. Bu durum uygun olmadığından şerif, uygun bir dille Cidde Valisi'nden durumun halledilmesini istemiştir. Ancak vali, Cidde hazinesinin zaruretini ortaya koyarak işi savuşturmuş̧tur. İşin soruşturulması da gündeme 
geldiğinden bunun için Cidde gümrükçüsü bulunan İbrahim Ağa görevlendirilmiştir. İnceleme sonunda şerifin bu konuda etkisi olamadığından ve daha önce belirttiği bazı maddelerde istidat gösterememesinden hadisenin meydana geldiği belirtilmiştir. Harcamalar normalden fazla olduğundan bundan böyle bir yük daha fazla akçe gönderilse de istenen asayişin sağlanamayacağ 1 beyan edilmiştir. Yukarıda beyan olunan hususlar ise Mahmud Paşa ve askeri ile ileri gelenler ile Medine Muhafızı Paşa ve Yenbu Muhafızı İzmirli Mehmed Reşid Efendi'lerin de malumatları olduğundan icap edilirse tekrar incelenebileceği belirtilmiştir (İ. MSM. 63/1815 (1264. C. 5)).

11 Mayıs 1848 'de Mekke Emiri'ne yazılan bir yazıda, Yemen ve Necid meselelerine dair Mekke Emareti başmuavini Kıbrıslı Tevfik Paşa, Cidde Valisi ve Yemen meselesi memuru Eşref Bey tarafından gönderilen bir takım tahrirat üzerine Yemen ve Necid havalisinin idaresi padişah tarafından tekrar incelenmiştir. Gelen yazılara göre Yemen meselesinin şimdilik çözüme yaklaştığından silah bırakılması gündeme gelmiştir. Padişah, Necid meselesine de özel bir önem atfetmiştir. Meselenin çözülmesine katkılarından dolayı padişahın onayı ile bir takım nişanların hazırlanması istenmiştir. Bunlar bir kıta nişan-1 ali, mir-i miranlık, mirü’l- ümeralık rütbeleri ve maaşlarının dahi yüzer bin kuruş artırılmadır. Muavin Kıbrıslı Tevfik Paşa'nın ise mirü'l- ümeralık rütbesi tevcihiyle maaşının 7.500 kuruşa çıkarılması hususuna da karar verilmiştir (A. MKT. 127/35 (1264. 6. 7)).

7 Haziran 1848'de Meclis-i Hakan-1 Adliye'de Yemen meselesi üzerine bir görüşme olmuştur. Buna göre, malum olduğu üzere daha önce Hicaz tarafına gönderilen 3 tabur nizamiye askerine dair Kıbrıslı Tevfik Paşa tarafından takdim olunan mazbatadaki bazı ifadelerin icabına bakı1masına dair irade, Seraskere sunulmuştur. Dâr-1 Şûrâ müzakerelerine dair bir kıta yazı Serasker tarafından Meclis-i Vâlâ'ya gönderilmiştir. Irak ve Hicaz Orduları'nın tertip ve ikmali hakkındaki tasavvur icabınca adı geçen ordunun müşirinin merkez memuriyetine alınması ve istihdam olunacak nizamiye askerinin Irak tarafindan tertip ve ikmal edilmesi gündeme gelmiştir. Bunun için adı geçen taburların yer değiştirmeleri hakkındaki görüşme ve her sene bunlardan bir taburu Kâbe'ye gelen hacılara refaket ettiğinden yine aynı mahalde kalmaları tavsiye edilmiştir. Ayrıca Cidde, Kâbe'ye 18 saat mesafede ve iki taburluk bir kışla dahi bulunmak hasebiyle adı geçen askerlerin Cidde'de ikame olunması ve Arabistan Ordusu'nda bir sene kalmış, oraların havasına alışmış olanlardan oluşturulması kararlaştırılmıştır. Adı geçen askerlerden meydana gelen kayıpların tamamı havadan icap etmeyip vefatın çokluğu geçen sene orada meydana gelen hastalıktan da ileri gelmiştir. Kayıpların önüne geçmek için Taif' in havası son derece iyi olduğundan, askerin hemen Taif'e geçirilmesi ifade edilmiştir (İ. MMS. 15/320 (1264. Ca. 7)).

Başka bir çözüm olarak bir önceki tavsiye kabul olunmadığ takdirde ordunun bir firkasının daima orada kalacak olmasından veya suyu çok havası güzel bir mahal tespitinden sonra buraya iki taburluk bir kışla inşasının da kâfi gelebileceği belirtilmiştir. Ancak ileride daha fazla asker gönderileceğinden bir kışla inşası lüzumu daha ortaya çıkacak ve bu da ziyadesiyle harcamaya neden olacaktır. Bu yüzden ortaya çıkacak sıkıntılara bakılmayıp bir alaylık kışla inşası ve adı geçen askerin hüsnü idare ve kumandası için orada bir ferikin olması zaruri görülmüştür. Şimdiki halde mevcut askerlerin bir miralay marifetiyle idaresi dahi mümkün olmadığından Ferik Mahmud Paşa'nın adı geçen mahalde kalmasında mahzur buyurulduğu halde bir müddet sonra alınması yerinde görülerek bölgenin ve askerin durumunun da göz önünde tutulması istenmiştir. Taif'te askerlerin ikamesine uygun mahaller olduğu için askerlerin hemen oraya naklolunması ve Taif'te bir kışlanın yapılmasına karar verilmiştir. Mekke'ye yakın olan mahallere ikame ve oralara zahire nakli ve sair eşyadan dolayı işlerin Cidde'den idare olunması 
uygun bulunmuştur. Seçilecek mevkide bir alay askerin Taif'e nakliyle durumun bu tarafa bildirilmek üzere ve daha önceden İstanbul'a çağırılan ve Seraskerlik makamınca Cidde'de kalması tavsiye edilen Ferik Mahmud Paşa'nın çağırılması ve durumun Serasker'e bildirilmesi Meclis-i Vâlâ tarafindan uygun görülmüştür (İ. MMS. 15/320 (1264. Ca. 7)).

9 Haziran 1848'de Mehmed Said imzalı bir yazıda Yemen'in mevcut durumunun 1slah edilmesine dair daha önce Hicaz'a gönderilen nizamiye askerinin şimdilik orada lüzumu kalmadığından ve askerler oranın havasına uyamadıklarından hayli kayıpları olduğu beyan edilmiştir. Ayrıca taburlarının eksikleri olduğundan bahisle nizamiye askerlerinin iadeleri veya adı geçen taburların birisinin diğerlerine ilavesiyle o havaliye zabitler gönderilmesi ve gerekli birtakım harcamaların yapılması noktasında Mekke Emareti başmuavini Kıbrıslı Tevfik Paşa tarafından daha önce bir yazı sunulmuştur. Her yerde olduğu üzere Yemen'de de asayişin sağlanması ve oranın devlete bağlanması için hayli asker bulundurulması lazım iken rivayet olunan kayıplara nazaran başka çaresinin aranması düşünülmüştür. Bunun için de toplanacak yeni askerlerin bu iklime uygun yerlerden toplanması ilk akla gelenlerden olmuştur. Ancak bu fikrin ilk olarak Dâr-1 Şûrâ-yı Askerîye ve Meclis-i Hass-1 Vükela'da görüşülerek padişah tarafindan karar verilmesi istenmiştir. 5 Şubat 1848 tarihli bu görüşlere dair daha sonradan çalışmalar yapılmıştır. Bunun için bu tezkere ve Hidivlikten gelen yazılar Dâr-1 Şûrâ-yı Askerîye ve Sadaret makamına gönderilerek buradan çıkan sonuçların padişahın görüşüne sunulmasına karar verilmiştir (İ. MMS. 15/320 (1264. Ca. 7)).

Bahsi geçen askerlerin durumu ve kışla inşası hakkındaki tasavvur 18 Haziran 1848'de Dâr1 Şûrâ-yı Askerîye'de ele alınmıştır. Kâbe'nin ihtiyacı olan bazı şeylerin alımı için geçenlerde İstanbul'a gelmiş olan Mekke Emareti başmuavini Kıbrıslı Tevfik Paşa tarafından Babıali'ye bir kıta müzekkere takdim olunmuştur. Müzekkerenin içeriğinde Osmanlı Devleti'nin bir parçası olan Yemen'de asayişin temini için oraya gönderilen nizamiye askerlerinin şimdilik meselelerin hallolmuş gibi gözükmesinden dolayı orada lüzumu kalmadığı ve oranın havasıyla uyumlu olamadıklarından birçok kayıp yaşandığı beyan edilmiştir. Sıkıntıyı aşmak için adı geçen askerlerin geri gönderilmesi ya da taburlardan birisinin diğerlerine ilave olunması tavsiye edilmiştir. Ancak nizamiye askerlerinin orada daha fazla bulunması lazım gelirken bölgede istihdam olunacak askerlerin oranın iklimine uygun olanlardan seçilmesi üzerinde durulmuştur. Bu tasavvurun Dâr-1 Şûrâ'ya havalesiyle bu konuda ve buna bağlı hususlarda Kıbrıslı Tevfik Paşa'nın diğer ifadelerinin Meclis-i Hass-1 Vükela'da ele alınması uygun görülmüştür. Oradaki askerin durumu ve bölgenin her türlü zarardan arındırılması öncelik olarak belirlenmiştir. Bunun için orada görev yapmakta olan ve askerin kumandası vazifesiyle bulunan Ferik Mahmud Paşa, oradan alınırsa Yemen'deki sıkıntının azalacağı ve Irak ile Hicaz Ordusu'nun yeniden tertip edilecek olması da bu kapsamda ele alınmıştır (İ. MMS. 15/320 (1264. Ca. 7)).

Buna göre Hicaz Ordusu'nun bir firkası bölgede olacağından ve Hicaz taraflarında istihdam olunacak askerin Irak havalisinden hazırlanıp gönderilmesi mümkün göründüğünden buna uygun bakılmıştır. Yine şu anda Cidde'de bulunan 3 tabur nizamiye askeriyle adı geçen ferik, bu ordunun mensupları olduğundan bu husustaki endişelerden biri de giderilmiş olur. Ancak bu iş ileride yapılacağından şimdilik adı geçen taburların yerlerinin değiştirilmesi hususunda bu taburlardan biri her sene hac mevsiminde hacıların güvenliği için Kâbe'de bulunduğundan bu nokta düşünülmesi gereken bir başlık olarak görülmüştür. Üstelik Cidde'de iki taburluk bir kışla bulunması ve Cidde'nin Kâbe'ye 18 saatlik bir mesafede bulunmasıyla bu taburların Cidde'de ikamet ettirilmesi yerinde bulunmuştur. Zaman içinde bu askerlerin Arabistan ordusunda bir yıl kalmış ve oranın havasına alışmış askerlerle değiştirilmesi yerinde görülmüştür. Böylece kayıpların azaltılması hesaplanmıştır. Yine askerin uğradığı telefatın bir nedeni de geçen sene 
bölgede meydana gelen hastalık olmuştur. Buna rağmen Taif'in havası ve suyu daha iyi olduğu ve yine Cidde'ye olan mesafesinin 18 saatten ibaret olduğu vurgulanmıştır. Orada asker bulunduğu sırada zahire ve diğer şeylerin nakli hususunda Cidde'den gönderilecekler cüzi masraflardan ibaret olacağından ve askerlerin sıhati için de böyle bir masrafa bakılmaması gerektiğinden askerin hemen oraya nakledilmesi istenmektedir. Ancak ileride askerlerin arttırılacak olmasıyla başka bir kışla binasına da ihtiyaç duyulacağından ve başka bir kışla yapmak gereksiz bir masraf olacağından nümayişe bakmaksızın ol havalide bir alaylık bir kışla inşası yapılması istenmiştir. Adı geçen askerin hüsnü idaresi ve kumandası için orada bir feriklik makamı gerekli olduğu ancak şimdilik miralaylık rütbesiyle idare edilebileceği üzerinde durulmuştur. Mevcut ferikin orada bulunmasının devlet adına bir sıkıntı doğuracak olmasından dolayı da bir müddet sonra oradan kaldırılması ifade edilmiş̧tir (İ. MMS. 15/320 (1264. Ca. 7)).

Cidde Valisi'nin takdim ettiği layihada gösterildiği üzere Yemen meselesi üzerine o tarafa gönderilen nizamiye askerlerine lüzum kalmadığı ayrıca Hicaz taraflarının suyu ve havasına uyum sağlayamadıklarından çok fazla ölenin olduğu bildirilmiştir. Yine çağırılan Ferik Mahmud Paşa'nın dahi o tarafta kaldığı sürece Yemen'deki Şerif Hüseyin'in, onun Yemen memuriyetiyle geldiğini düşünecek olmasından dolayı endişeden kurtulamayacak olmasından buna da bir çözüm bulunmas1 istenmektedir (İ. MMS. 15/320 (1264. Ca. 7)). Meseleler daha kritik bir hal almaya başlayınca bölgedeki önemli isimlerden olan Şerif Muhammed bin Avn ile San’a İmamı ve Hüseyin Paşa'ya yazılar gönderilmiştir.

17 Haziran 1848'de Şerif Muhammed bin Avn ile San'a İmamı ve Hüseyin Paşa'ya yazılan yazılarda, San'a İmamı'yla Hüseyin Paşa arasında vuku bulan husumetin Yemen meselesi hakkında daha önceki mütalaa ve kararı değiştirdiği ifade edilmiştir. Yemen'in şimdiki haline nazaran işin çözülmesine dair mahalli tedbirler ve lüzumu olan akçe ve asker keyfiyeti, Eşref Bey'in gelmesiyle Cidde Valisi paşayla müştereken birkaç kıta tahrirat ve evrakta sunulmuştur. Hicaz'ın zabıta ve rabıtası için uğraşmakta olan ve Yemen'in durumu üzerine gelen yazılardan ve Kıbrıslı Tevfik Paşa'nın tanzim ve takdim eylediği layiha ve paşa tarafından yapılan ifadeler ve tebligat üzerine durum görüşülmüştür. O tarafın daha iyi idaresi ve Hicaz’a yakın Aden gibi yerlerde ecnebiler peyda eylemiş olmasından o tarafların durumunun idare altına alınması ve bunun dış politikaya yansımadan hakimane bir suretle çözülmesi ayrıca Yemen işlerinde harcanmak üzere 5.000 kese akçe Cidde Defterdarı Sırrı Efendi'ye gönderilmiştir. Bu miktarın birazı kalırsa onun da Hicaz'a aktarılması düşünülmüştür. Nizamiye askerlerinin süratle gönderilmesi gerekirse de bu askerlerden oranın suyu ve havasına alışamayanların olabileceği belirtilmiştir. Bu askerlerin gönderilmesinde fayda varsa da Hicaz tarafından o bölgenin havası ve suyuna alışkın başıbozuklardan 8.000 civarında asker toplanabileceği ancak Mekke ve çevresinin muhafazasına halel gelmemesine itina edilmesi istenmiştir (A. MKT. 134/66 (1264. 7. 15)).

Bunun yanında Misır Valisi eliyle İskenderiye tarafindan 800 veya 1.000 nefer askerin de toplanması istenmiştir. Bunların Hicaz'a varana kadar masraflarının da Yemen tahsisatından karşılanması söylenmiştir. Bir de Cidde Eyaleti'nde mevcut olan şotiye tabir edilen iki gemiden başka ihtiyaç duyulan malzeme vesair işlerin yapılabilmesi için Mısır Valisi'nin 3 büyük 2 küçük gemi ve 1 de vapur tedarik etmesi istenmiştir. Bunlara ilave olarak denizden gidecek başıbozuk askerini kumanda etmek ve iş bittikten sonra kaymakam olarak kalacak, oranın durumuna vakıf birisinin mir-i miranlık veya emirü'l- ümeralık rütbeleri verilerek orada kalması düşünülmektedir. O tarafta bu şekilde bir zat bulmak pek zor olacağından Kıbrıslı Tevfik Paşa veya başka birinin seçilmesi gündeme gelmiştir. Orada görevlendirilecek kişilerin rütbeleri ve nişanları hususunda hazırlık yapılıp Araplar için bir de şerif unvanı ile birinin atanıp atanmayacağ 1 da söz konusu olmuştur. Vazife sırasında faydalı işler görecek olanlara da Cidde Valisi 
eliyle nişanlar verilmesi için hazırlık yapılması ve eğer bunlara gerek kalmazsa İstanbul'a nişanların iade edilmesi istenmiştir. Yine şimdiki San'a İmamı'na galebe geldikten sonra eğer imam Osmanlı Devleti'ne yakın olmayı kabul ederse onun, etmezse akrabalarından birinin eğer o da münasip görülmezse Yemen'de saygınlığı olacak birinin şerif unvanı ile Yemen'de göreve getirilmesi kararlaştırılmıştır. Bunun için gerekli resmi evraklar dahi hazırlanmış ve durumuna göre hareket edilmesi istenmiştir. Bunun için de bölgedeki yetkililer hazırlık yapmaları konusunda bilgilendirilmişlerdir (A. MKT. 134/66 (1264. 7. 15)). Konuyla ilgili 17 Haziran 1848'de Maliye Nazırı'na yazılan bir yazıyla Mekke Emareti muavini Kıbrıslı Tevfik Paşa ile Cidde hazinedarı Ahmed Ağa işbu Salı günü avdet edeceklerinden bunların taltif edilmelerine karar verilmiştir. Yine Tevfik Paşa'ya 50.000 ve Ahmed Ağa'ya dahi 20.000 kuruş verilmesi uygun görülmüştür (A. MKT. 135/1 (1264. 7. 15)); A. MKT. 135/14 (1264. 7. 16)).

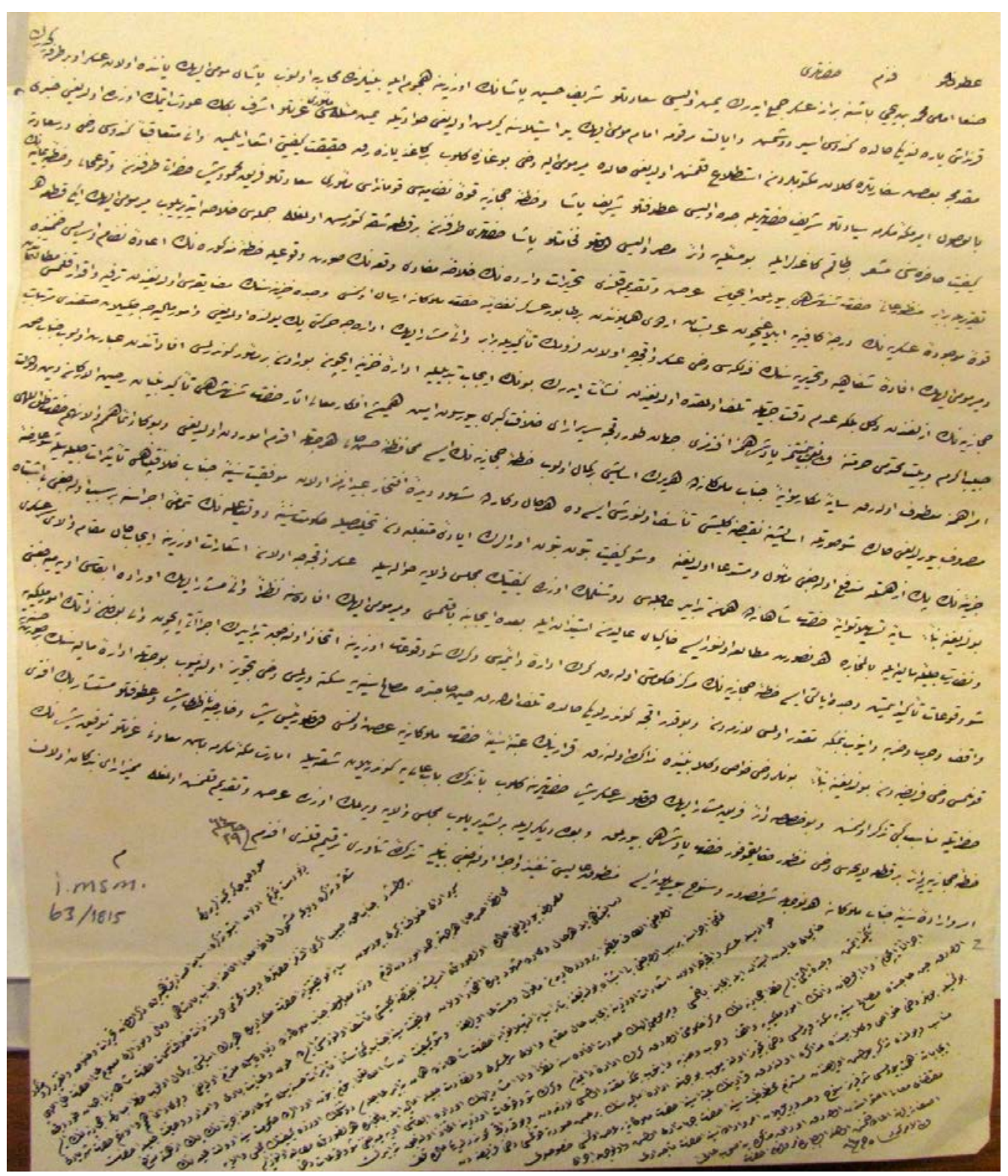

Fig. 2. Muhammed bin Yahya ve Şerif Hüseyin Arasındaki Kavga Hakkında Bilgi Veren Bir Belge (I. MMS. 63/1815 (1264. C. 5)) 
Mısır Valisi'ne 22 Haziran 1848'de gönderilen bir yazı ile Yemen meselesi için şerife verilecek 5.000 kese akçenin Maliye Hazinesi'nden verilmesi ve bunun Mekke Emareti muavini Kıbrıslı Tevfik Paşa ile gönderilmesi kararlaştırılmıştır. Mazlum Bey'in de eşlik ettiği bu akçenin kâmilen Şerif hazretlerine verilmesi hususunda bilgilendirme yapılmıştır (A. MKT. 135/75 (1264. 7. 20)). Aynı tarihte Mısır Valisi'ne yazılan bir başka yazıda, daha önce belirtildiği ve emredildiği üzere Yemen meselesinin çözülmesi hususunda Mısır'dan toplanacak ve Mekke Emareti başmuavini Kıbrıslı Tevfik Paşa marifetiyle sevk olunacak askerlerin Hicaz'a varıncaya değin yapılacak tüm masrafları devletçe ödenecek denmiştir. Ayrıca başıbozuk askerinin nizamiye askeri gibi elbise, silah ve diğer ihtiyaçları Mısır tarafından karşılanmayıp kendilerine bu gibi harcamaları için bir miktar iane verilecektir. Cidde'ye kadar gerekli sayıdaki deve ve Süveyş’ten Cidde İskelesi'ne kadar lazım gelen kayıkların Mısır vergisinden ödenmesi muavin tarafından ifade olunmuştur. Meselenin hüsnühâl üzere çözülmesi ve düzenin tesisi için askerlerin tertip edilmesiyle Kıbrıslı Tevfik Paşa marifetiyle yapılacak işlerin bildirilerek bunların hazine tarafından karşılanmasına karar verilmiştir. Mısır tarafına da bu konuda bilgilendirme yapılmıştır (A. MKT. 135/75 (1264. 7. 20)). Bu yazışmaların olduğu aynı günde ise Yemen meselesine memur olmasından dolayı Mekke Emiri Şerif Muhammed bin Avn tarafına topçusuyla birlikte bir buçuk çapında iki kıta top verilmesine karar verilmiştir. Topların gönderilmesi için Kıbrıslı Tevfik Paşa'nın süratle gitmesine lüzum göründüğünden adı geçen topların verilmesi elzem görünmüştür (A. MKT. 135/75 (1264. 7. 20)).

Mazlum Bey Efendi'ye 28 Haziran 1848'de yazılan bir yazıda, Mekke Emareti muavini Kıbrıslı Tevfik Paşa'nın 25 neferden ibaret olan dairesi halkıyla beraber yanında götüreceği iki kıta çarh topu ve mühimmat ve diğer levazımatıyla perşembe günü hareket edecekleri ve bunların Mısır Kumpanyası vapuruyla gönderilecekleri belirtilmiştir. Vapura bu iş için ne kadar ücret verileceği ve bu gibi kumpanya vapurlarına asker ve sair memur bindirildiği vakit ücretlerin yarısı verilmek mutad olduğundan bunlar dahi bu vechle mi hesap olunacak diye sorulmaktadır. Ne şekilde ödenecekse hemen bildirilmesi istenmektedir (A. MKT. 136/56 (1264. 7. 26)).

29 Temmuz 1848'de Mekke başmuavini Kıbrıslı Tevfik Paşa'dan gönderilen bir yazıyla Yemen meselesi hakkında yapılmakta olanlarla ilgili bilgi verilmiştir. Bu yazı Şaban ayının başında İstanbul'dan hareket eden ve aynı ayın dördüncü günü İskenderiye'ye varıp İbrahim Paşa'ya teslim edilip gerekli emirler verilmiştir. Hesap edilen meblağ ve adı geçen gemiler paşaya iltizam kılınıp başıbozuk askerinden toplanabildiği kadarının toplanmasına ve şu aralık Mısır'da kolera hastalığı olmasına binaen asker toplanması caiz görünmeyerek oradan dahi Süveyş'e ve oradan da gemilere binerek Cidde İskelesi'ne sevk ve irsal olunmakta olduğu bildirilmiştir. Ancak şu anda Hicaz tarafına bir tahrirat gitmediği beyan edilmiştir. Sabık Yemen Valisi Şerif Hüseyin Paşa bir şekilde San'a İmamı tarafından hapse atılınca olayın gidişatı farklı bir hal almıştır. Şimdiki halde Şerif ve Cidde Valisi tarafından bir irade olmadıkça Yemen tarafina ordu sevki ancak uygun mevsimde yapılabilecektir. Ancak Şerif Hüseyin Paşa hapisten kurtulup yine Yemen Sahilleri ile Yemen ve Şerif haklarında ne merkezde irade olur ise bu tarafa gelmek üzere olan Cidde Defterdarı Sadi Efendi'yle gelecek emirler ve vali taraflarına ihbar edileceklerin yazılacağı haber verilmiştir (İ. MMS. 63/1821 (1264. N. 20)).

Şerif Hüseyin tarafından gönderilen ve tercüme ettirilen açıklamalarda son durum hakkında bilgi verilmiştir. Buna göre, Şerif Zibu Nahiyesi’nde San’a İmamı tarafindan hapsedilmiştir. Yeğeni Hasan Yam onu almaya gitmiş ve Yemen askerlerinden 8.000 asker ile gelip Zibu nahiyesini muhasara ederek 18 günden sonra kaleye hücumla hapisten amcasını kurtarmış ve karşı taraftan da epey kişi katledilmiştir. Bu münasebetle Şerif Hüseyin salıverilirse hapis süresince oğlu Hüseyin, Asir'e çıkmış olduğundan Aid bin Meri askerler ile Asir'den Cebi’ye 
gelmektedir. Adı geçen Aid bin Meri'nin Hüseyin'in kardeşi Haydar ile mülakat ettiği ve San'a İmamı'nın bakiye askerleri ile Moha Kalesi'nde Hüseyin'in muhasarasında oldukları haber verilmiştir. Daha sonra gelen haberlerde şerifin idareyi eline almaya başladığı ve Moha etrafındaki imamın askerlerinden çoğunun firar ettiği bildirilmiştir (İ. MMS. 63/1821 (1264. N. 20)).

Yemen'de gelişmeler kritik bir noktada iken 30 Haziran 1848' de Maliye Nazırı'ndan Mekke Emareti muavini Kıbrıslı Tevfik Paşa ile Hicaz'a gönderilecek iki kıta topun tertip olunan 1 nefer çavuş ve 2 nefer onbaşı ve 20 nefer topçusuna benzerleri gibi 3'er aylık peşinen verilmesi istenmiştir. Yine icap eden 5.205 kuruş maaşlarının hemen hazineden verilmesi belirtilmiştir. Ayrıca Tophane-i Amire müşiri ile muhabere ederek bu miktarın hemen Tophane-i Amire'ye verilmesi hususunda karar verilmiştir (A. MKT. 136/96 (1264. 7. 28)). 6 Temmuz 1848'de ise Şerif hazretleriyle Cidde Valisi'ne İstanbul'dan gönderildiği gibi şimdi de Mekke mühimmat anbarında saklanılmak üzer kendilerine 1 mirliva çadırıyla 2 adet kaba çadırın verilmesi Mekke Emareti başmuavini Kıbrıslı Tevfik Paşa tarafından istenmiştir. Adı geçen çadırların verilmesi uygun olduğundan ve bu çadırlar Deavi Nazırı'nın bineceği vapurla gönderileceğinden mühimmat ambarından verilmesi istenmektedir (A. MKT. $137 / 77$ (1264. 8. 4)). Konuyla ilgili olarak 10 Temmuz 1848'de Tophane-i Amire Müşiri ve Mühimmat-1 Harbiye Nazırı'na haber verilmiştir (A. MKT. 138/18 (1264. 8. 8)).

Şerif Hüseyin'in durumu ile ilgili 31 Temmuz 1848'de bölgeden daha ayrıntılı bilgi verilmiştir. Yemen Valisi Hüseyin Paşa'nın biraderzadesi muavenetiyle kurtulması üzerine Kıbrıslı Tevfik Paşa'nın Mısır'dan teçhiz edeceği başıbozuk askerlerine lüzumu kalmadığı fikri ortaya çıkmıştır. Buna göre Mekke emiri ve Cidde valisinin resmi tahriratında da olmadığı için bu haberlerin pek de gerçek hükmüne konulamayacağı ifade edilmiştir. Ancak yine de detaylı incelemelerin yapılması istenmiştir. Bundan başka eski askerlerin yeni askerler ile değiştirilmesi lüzumundan dolayı 500 nefer miktarının mevcut askerlerden karşılanması ve bir miktarının dahi Kıbrıslı Tevfik Paşa tarafından belirtildiği üzere İbrahim Paşa tarafından toparlanacağı yazılmıştır. Yine İbrahim Paşa'ya havale buyurulan 5.000 kese akçenin hemen Mısır'dan gönderilmesiyle gerek lazım olan askerlerin teçhizi gerekse de lazım olan gemilerin sevkinin yapılacağ 1 belirtilmiştir (İ. MMS. 63/1821 (1264. N. 20)).

Mısır'daki durumla ilgili 12 Ağustos 1848 'de bilgi verilmiştir. Verilen bilgiler Mısır'dan toplanacak asker maddesinde son derece mühim bir nokta teşkil etmektedir. Buna göre, İbrahim Paşa'nın bir gemi ile geldiği İskenderiye'deki kolera hastalığından dolayı Mısır'da günlük 300 nefere kadar ölenler çıkmış iken 162 nefere kadar indiği belirtilmiştir. Hastalığın en kuvvetli olarak İskenderiye'de hissedildiği beyan edilmiştir. Yine Mehmed Ali Paşa'nın hastalığının devam ettiği söylenmiştir. Bu haberler İbrahim Paşa'dan alınarak İstanbul'a ulaştırılmıştır (İ. MMS. 63/1821 (1264. N. 20)). Konuyla ilgili 17 Eylül 1848’de Mazlum Bey Efendi'nin Rodos'tan iki kıta şukkası Mekke Emareti başmuavini Kıbrıslı Tevfik Paşa'nın dahi Mısır'dan bir kıta tahriratı gelmiştir. Şukkaların birisinde hamd olsun kolera hastalığının Mısır'da azalmaya başladığı belirtilmişse de İskenderiye'de biraz daha şiddetlenmiş olduğu ve İbrahim Paşa'nın dahi bir gemiyle Rodos önünde bulunduğu ifade edilmektedir. Diğer şukkayla paşanın tahriratı içeriğinde dahi rivayetlere nazaran Yemen Valisi Hüseyin Paşa, San'a İmamı'nın hapsinden kurtulduğu ve Yemen'i elde etmeye çalıştığı belirtilmektedir. Eğer bu havadis üzerine Yemen meselesi hakkında girişilen teşebbüslerin terki lazım gelirse de haber resmi surette olmadığından yine Kıbrıslı Tevfik Paşa'ya verilecek askerler ve akçenin tertibinde gecikme meydana getirilmemesi istenmiştir. Şimdilik gelen haber doğru kabul edilse de yeni bir haberle terki caiz görünemeyeceğinden oraca verilen karar münasip olup bu maddenin nerelere kadar sahih olduğu bundan sonra bilinebileceğinden ve ne tedbir almak lazım gelirse sonra 
mütalaa olmak lazım geleceğinden şimdilik tahriratın pek hükmü olmayıp padişaha sunulmuştur. Bu konuda şimdilik gelen tahrirat ve şukkalara pek de sahih gözle bakılmaması tavsiye olunmuştur (İ. MMS. 63/1821 (1264. N. 20)). 31 Ekim 1848'de de Yemen meselesine dair sabık Cidde Valisi ve Ferik Mahmud Paşa ile müşterek yazılar göndermişlerdir. Bu yazılara dair verilen cevapta ise padişahın da isteği ile bu meselenin bir an önce çözülmesi bir kez daha ifade edilmiştir (A. MKT. $157 / 47$ (1264. 12. 3)). Hazırlıklar kapsamında Yemen meselesinde memur olan Mekke Emiri Şerif Muhammed bin Avn tarafına topçusuyla birlikte bir buçuk çapında iki kıta top verilmesine dair irade çıkmıştır. Hemen ulaştırılabilmesi için Kıbrıslı Tevfik Paşa'nın gayretine ihtiyaç duyulmuştur. Kıbrıslı Tevfik Paşa'nın gidişiyle topların gönderilmesi icap ettiğinden bunlar hemen verilerek Mısır'a vardıklarında alınması ve Misır'dan gönderileceklerle birleştirilip hemen yerlerine ulaştırılması istenmiştir (A. MKT. 236/54 (1265)).

\section{Hudeyde'nin Alınması ve Kıbrıslı Tevfik Paşa'nın Ölümü}

Beyrut hadisesinden sonra Mehmed Ali Paşa'nın askerleri, kimi yerler gibi Yemen'i de boşaltmak zorunda kaldılar. Fakat bu sırada Yemen'e asker gönderme imkânı olmadığından oranın yönetimi bölgesinde büyük bir etkinliğe sahip olan Ebu Ariş Şürefası'ndan, Şerif Hüseyin bin Ali'ye tevdi edilmişti. Şerif Hüseyin, Yemen'i çok güzel idare etmişse de akrabaları arasında çıkan bir anlaşmazlık yüzünden karışıklıklar başlamış ve San'a'da bulunan İmam Muhammed Yahya'nın Tihame'ye inmesine neden olmuştu. Muhammed Yahya, Hudeyde hariç bütün Tihame'yi ele geçirerek, Şerif Hüseyin'i esir almıştı. Fakat Hudeyde'de ikamet etmekte olan Şerif Hüseyin'in yeğeni Şerif Hasan'ın amcasını kurtarmaya kalkışması üzerine, İmam Muhammed Yahya tekrar San'a'ya kaçmıştı. Tam da bu sıralarda İngilizler Aden'e yerleşmeye başlamıştı. İngilizlerin Aden'e yerleşmesi, daha sonra Hadramut, Nevahi-yi Tisa ve Yemen'in öteki bölgelerinde birçok gailelere sebep olacak, Yemen'in ikiye ayrılması ve günümüzde bile durmadan kardeşkanı dökülmesinin sebebi, Yemen'in Aden Bölgesi'nin bu şekilde İngilizlere terk edilmesine neden olacaktı (Sirma 1997, 377; Sirma 2008, 53-55).

1849 yılının başlarında Osmanlılar Yemen'de kontrolü yeniden sağlamaya karar verdiler. Osmanlı birlikleri Kıbrıslı Tevfik Paşa komutasında Mart ayında Hudeyde ve Kamaran için yola çıktı 19 Nisan 1849'da paşa Hudeyde'ye ulaştı. Bu sırada Hudeyde, Şerif Hüseyin'in idaresi altındaydı. Şerif Hüseyin, Osmanlı birlikleri gelince Ebu Ariş'e döndü. Bir başka Osmanlı birliği bu arada Kamaran'ı ele geçirdi. Kıbrıslı Tevfik Paşa, Salif, Hudeyde ve Beytü’l-Fakih'i kapsayan valiliği üzerine aldı. Tihame'nin güneyinde ise Muhammed bin Avn'ın oğlu Abdullah vali olarak kald1 (Baldry 1976, 162).

Yemen'in bu karışıklığını Babıali'ye bildiren Mekke Muavini Kıbrıslı Tevfik Paşa'nın bir layihası Abdülmecid'in dikkatini çekmişti. Bu layiha üzerine de Kıbrıslı Tevfik Paşa'yı Yemen'i geri alması için oraya gönderdi. Bunun üzerine Mısır ve Hicaz'da donatılan 3.000 kadar Osmanlı askeri Cidde'den hareket ederek 1849'da Hudeyde Limanı'na vardı. Hudeyde kaymakamı Şerif Hasan'ın direnmesi üzerine savaş başladı ve ertesi gün de Şerif Hasan şehri teslim etmeye mecbur kaldı. Böylece Yemen ikinci kez Osmanlı idaresine girdi. Hudeyde'yi bu şekilde teslim alan Kıbrıslı Tevfik Paşa ile Mekke Şerifi Muhammed bin Avn, San'a'yı da Osmanlı egemenliği altına almak amacıyla Mekke Nakibü's-Sadatı Seyyid İshak efendi'yi bir mektupla San'a İmamı Muhammed Yahya'ya gönderdiler. Kendisine her tarafta başkaldıran Arap kabilelerinden kurtulmak ve belki de bir paye almak düşüncesiyle Muhammed Yahya, San'a'dan Hudeyde'ye gitti. Burada belli esaslar üzerinde görüşmeler oldu (Sırma 2008, 53-55). Kıbrısı Tevfik Paşa'nın da Hudeyde'de olduğu bir sırada San'a İmamı Hudeyde'ye gelerek bir anlaşmaya vardı. Buna göre küçük bir Osmanlı askeri birliği San'a'da olacak, gelirler İmam ve Osmanlı Devleti arasında ikiye bölünecek, Cuma günleri hutbede padişahın adı zikredilecek ve 
San'a çevresinin Osmanlı hâkimiyetinde olacağı kabul edilecekti. Bunun üzerine Kıbrıslı Tevfik Paşa bir miktar kuvvetle San'a'ya gitti. Ancak bu anlaşmaya kabileler tepki gösterdiler. Çıkan karışıklıkta Kıbrıslı Tevfik Paşa'yla San'a'ya gelen şehirdeki birçok asker biraz da Kıbrıslı Tevfik Paşa'nın tedbirsizliğinden hayatını kaybetti (Baldry 1976, 164-165).

Her ne kadar Kıbrıslı Tevfik Paşa maiyetindeki askerle birlikte bir tek silah patlamadan San'a'ya girmişse de gerekli önlemleri almadığ için birçok askerin boş yere ölmesine sebep olmuştur. Nitekim Kıbrıslı Tevfik Paşa, İmam Muhammed ile San'a'ya girince çevredeki kabileler daha da galeyana gelmişler ve İmam Muhammed'i imametten uzaklaştırarak yerine Ali Mehdi denen bir başkasını getirmişlerdir. Bütün olup biteni İmam Muhammed, Kıbrıslı Tevfik Paşa'ya haber verdiği halde Tevfik Paşa, söylenenlere kulak asmamış ve askerini San'a sokaklarına salmıştır. Kimi berbere kimi hamama giden askerlerin bu dağınıklığını gören halk, onlara saldırmış ve buldukları yerde öldürmüşlerdi. Kaçabilenler de Tevfik Paşa ile birlikte kaleye sığınmış ve burada 25 gün mahsur kalmışlardır. Bu arada eski İmam Muhammed Yahya hapsedilmiş daha sonra da öldürülmüştür. Sonunda da yeni İmam Ali Mehdi'nin himmetiyle Tevfik Paşa kaleden çıkarak perişan bir halde ve imam himayesinde Hudeyde'ye dönmüştür (S1rma 2008, 53-55).

Rütbe ve nişan verilmesi gibi işler tamamlandıktan sonra Kıbrıslı Tevfik Paşa İstanbul'a gönderdiği yazılarında memuriyeti üzerine Cidde'ye vardıktan sonra Yemen tarafına doğru harekete geçtiğini bildirmektedir. Tevfik Paşa, Hudeyde Limanı'na ulaştı̆̆ını oraya varınca Şerif Hüseyin'in dahi şehirde olmasından dolayı kendisiyle görüştügünü beyan etmektedir. Ertesi gün tekrar tüccar ve diğer kesimlerle toplanılan cemiyette aldığg emirleri açıkladığını söylemiştir. Bunun üzerine Şerif Hüseyin'le tekrar görüştüğünü, ardından 21 pare top atış1 yapıldığını ve mecliste müzakereler olduğunu beyan etmiştir. Bunun yanında Cidde Valisi paşayla Cidde'de müzakere olunarak kaleme alınan layihanın Şerif Hüseyin'e Arapça olarak verildiğini ilave etmiştir (A. MKT. MHM. 2/73 (1263. 9. 27)).

Kıbrıslı Tevfik Paşa açıklamalarına devam ederek Şerif Hüseyin'e gerekli açıklamaları yapmıştır. Buna göre, kendisinden isteyeceği her ne ise yapılacağını söylemiş̧tir. Tevfik Paşa başka açıklamalar da yapmıştır. Buna göre, Mekke Emiri hakkında yürürlükte olan usul devam ettirilerek Yemen Emareti kendisine bırakılmıştır. Tevfik Paşa Şerif Hüseyin'e: "Size bunun için münasip maaş ve tahsisat verilmesi asayiş için miktarı kadar asker ve bir memur verilmesi size duyulan itimattandır. Hakkınızda kimsenin bir söz söylememesi mümkün değildir" demiştir. Şerif Hüseyin verdiği cevapta: “şu anda Yemen'in gelirleri yeterli düzeyde olmadiğından bir memur ve yeteri kadar askerin bu gelirler tarafindan karşılanamayacağl ortadadır. Zaptiye işi bana havale buyurulur ise yeni masraflar bertaraf olacă̆ından gelecek olan memurun ihtiyacını da karşılayabilirim. Bunun yanında zaptiyenin dahi uhdemde olmasını tekrar ederek padişahtan dahi isteyeceğim zaptiye dahi bana ihsan buyurulsun" demiştir. Ayrıca: "Yemen zaptiyesine memur olacak kişiden daha fazla Osmanlı Devleti tarafina hüsnü hizmet ve vazife etmez isem Osmanlı Devleti'nin gücü buradaki her sıkıntıyı aşmaya muktedirdir. Bundan maksadım Yemen hasılatını elde etmek değildir. Bütün varidat ve masraflar Osmanlı Devleti tarafindan kabul edilerek bendenize mahsus bir gümrükçü ve ikişer üçer kâtip verilsin. Bir de Yemen Emareti bundan sonra evlatlarıma olacak şekilde bir ferman buyurulsun. Bunlardan başka durumum üzere her sene bir kıta nişan ihsan buyurulmasını temenni ederim. Böylece bu durumu padişaha harfi harfine arz etmeniz ve aramızda vuku bulan müzakerenin sonucunu Mekke Emiri ve Cidde Valisi'ne ifade etmenizi de rica ederim” demiştir. Tevfik Paşa bu durum üzerine, Yemen meselesinin çözümü padişahın isteği olduğundan ve şerifin isteklerini yerine getirmemek uygun düşmeyeceğinden Mekke Emiri ve Cidde valisinin hüsnü tevcihleri belirtil- 
melidir görüşündedir. Daha önce arz ve ifade olduğu üzere Hudeyde'de oturan Hacı Yusuf oranın durumuna vakıf ve bize yakın olduğundan ve şerifin yanında muavin gibi olduğundan kendisine Kapıcı Başı rütbesinin ihsan buyurulmasını münasip gördüğünü beyan etmiştir (A. MKT. MHM. 2/73 (1263. 9. 27)).

Kıbrıslı Tevfik Paşa, Yemen meselesinin beyan olduğu üzere şimdilik bu şekilde çözülmesi kararlaştırıldığı takdirde şerife hangi rütbeden nişan verilmesinin münasip olacağını bu tarafta Mekke Emiri ile müzakere ettiğini bildirmiştir. Necid Emiri bulunanlar Yemen hâkimine nispetle meziyetçe pek aşağıda iken Necid Emiri'ne bir kıta Istabl-i Âmire payesi ihsan buyurulmuştu. Şerif Hüseyin'e, Necid Emiri'nin bir rütbe daha ilerisinde tutularak mir-i miranlık nişanın ihsan buyurulması münasip görülmüştür. Kezalik her sene Şerif Hüseyin tarafına bir ferace verilmesi irade olunduğu halde padişah tarafindan Hüseyin'in Mekke Emiri'ne gönderilmesi mutad olan feraceden bir kat aşağıda kırmızı bir ferace alması münasip görülmektedir. Bu işle gidecek memurların İstanbul'dan gönderilmesi fazlaca masrafa sebep olacağından bu taraftan Arapça bilen ve şerif ile münasebeti olan biri tarafından gönderilir ise daha uygun olacağını haber vermiştir. Mekke Şerifi'nin ve Cidde Valisi'nin söylemeye hacet olmayan himmetleri ve yardımları ile bu haber gönderilmiştir. Kıbrıslı Tevfik Paşa: "Şimdilik ögrenebildiğim Yemen masraflarının bir kıta beyannamesi de bu yazıma ilave edilmiştir" demiştir (A. MKT. MHM. 2/73 (1263. 9. 27)). Bu gelişmeler yanında Kıbrıslı Tevfik Paşa, Cidde Hazinesinden almakta olduğu maaşına da bir miktar zam istemiştir (A. MKT. 94/85 (1263. 10. 3)).

29 Ocak 1849'da Cidde Valisi'nden gelen bir yazıda Kıbrıslı Tevfik Paşa'ya gerekli hatırlatmalar yapılmıştır. Buna göre, Yemen'in zapt ve kontrol altına alınmasında ve bu işlerin düzenlenmesinde Şerif hazretlerine yazılar gönderildiği bildirilmiştir. Bu konuda sevki lazım gelen askerin kumandasıyla Yemen'in zaptiye ve maliyesine tayin olunacak şahıslar, Araplardan seçilecek olanlar ve eşraftan isimler için şerifin tayin edilmesi emirin onayına bırakılmıştır. Mesele son derece mühim olduğu için emir ile irtibatlı olunması tavsiye edilmektedir. Yemen'in güzel bir şekilde rabıtasının arttırılması için çalışılması ve bunun için birkaç defa meclis toplanarak iradenin gerçekleştirilmesine dikkat edilmesi istenmektedir. Konuyla ilgili emirle iyi bir şekilde çalışılması tavsiye edilerek şimdiye kadar ki tehirin defterdarın olmamasından kaynaklandığı ifade edilmiştir (A. MKT. 171/60 (1265. 3. 5)).

31 Mart 1849'da Yemen meselesinin çözümü konusunda Tevfik Paşa ve Abdullah bin Şerif Paşa'nın şukkalarından Yemen'in idaresinin Şerif Hüseyin'e bırakılmasının pek de uygun olmadığı anlaşılmıştır. San’a İmamı tarafından verilen cevabı da içeren Mekke Şerifi'nin gönderdiği tahriratlar da İstanbul'a ulaşmıştır. Midi ve Hudeyde Kaleleleri'nde mevcut top ve mühimmatın bir kısmı daha önce Ebu Ariş adlı kaleye nakledilmiştir. Önceki yazıdan malum olduğu üzere Şerif Hüseyin'in biraderi Şerif Hasan bu duruma muhalefet etmiştir. Şerif Hüseyin'in gelişinde Ebu Ariş Kalesi kendisinde kalmak, etrafındaki Araplar uhdesinde olmak üzere emirü’l- ümeralık rütbesi tevcihi ve kendi durumuna uygun maaş ve denize yakın, dağ ve çöldeki bilcümle aşiretler ve kabilelere hâkim olması inhisar kılınmıştır. Bunun yanında aşiret ve kabilelere hizmet ederek San'a'nın fethine dahi iştirak etmiş ve sekiz nefer evladını dahi rehin vereceğini beyan ve tekrar etmiş olan ve nice senedir San'a İmamı'nın kuvvetlerinden olarak oldukça fazla kabilesi bulunan Ali Hamide adlı şeyh, Şerif Hüseyin kendisi üzerinde bir rütbe alınca onunla arası bozulmuştur. Ali Hamide, Şerif Hüseyin ile arasını bozunca Şerif Hüseyin kendi aşiret ve kabilelerini ihmal ederek dağa çekilmiştir (A. MKT. 216/15 (1265. 9. 7)).

Yemen Eyaleti hakkına Cidde Valisi tarafindan kaleme alınıp takdim kılınan layihada Moha ve Hudeyde Kaymakamı olmak üzere eyalet ikiye taksim ile birine Tevfik Paşa diğerine Abdullah bin Şerif Paşa'nın tayin kılınmaları istenmiştir. Ancak Şerif bu hadiseler sırasında 600 
nefer başıbozuk süvari ve bunun dişında da bir miktar kuvvetle gelince ve işin uzamasından mı ya da başka bir nedenle mi bilinmez Yemen'in tamamına Tevfik Paşa kaymakam olarak atanmıştır. Bunun üzerine Abdullah bin Şerif kendi kafasına göre bir miktar adamını gümrüklere ve başka yerlere tayin ederek isteği konusunda israrcı olmuştur. Bu konudaki hadiseler Hudeyde Mal Müdürü Safi Efendi'nin yazılarıyla bildirilmektedir. Eyalet hakkında ne şekilde hareket edileceğine dair sözlü veya yazılı bir irade yoksa da Osmanlı Devleti'nin hiçbir yerinde ayrılık gayrilık gözetilmemelidir. Memurlar tarafından istenilen maddelere dair ne şekilde cevap verilmek ve nasıl davranılmak icap edeceği ve Tevfik Paşa'nın Hudeyde Mal Müdürü Hakkı Efendi hakkındaki tahriratı ulaşmıştır. Bunlarla ilgili gerek Cidde Valisi tarafından gelen ve gerek ondan sonra gönderilen yazılarda Tevfik Paşa'nın yazılarıyla ve daha önce Moha ve Hudeyde olarak eyalet iki kısmı ayrılacak iken ve Moha Sancă̆ı'na Abdullah bin Şerif Paşa getirilecekken, Tevfik Paşa ile San'a İmamı arasında bir mukavele olmuştur. Bu sırada Şerif Hüseyin ile Ali Hamide arasında bir nefret olmasından ötürü İmam eliyle Şerif Hüseyin o taraftan savuşmuştur. Bu durum vaziyeti sıkıntıya sokmuştur. Şerif Hüseyin, İmamın hakkından gelebilecekse de Ali Hamide ile arasında olan mevzudan dolayı bu iş gerçekleşmemiştir. Bu hadiselerin kilit bir eyalet konumunda olan Asir'e sıçrama ihtimali ise Cidde Eyaleti'nin asayişi için zararlı görülerek şimdiki halin tedbire muhtaç olduğu belirtilmiştir. Her ne kadar Cidde Valisi tarafindan tedbir icap etmeyeceği beyan edilse de şimdiye kadar Yemen Eyaleti'nin gelirlerinin sıkıntıda olması işlere sekte vurmaktadır. Orada bulunan asker ve zabitlerin maaşları oranın gelirlerinden karşılanıyorsa da şimdiki halde bunlar mümkün olamamaktadır. Bu yüzden askerlerin ve subayların maaşlarının ve tayınlarının ne şekilde karşılanacağına dair İstanbul'dan görüş istenmiş̧tir (A. MKT. 216/15 (1265. 9. 7)).

15 Haziran 1849 'da Yemen meselesi hakkında şerif ve Abdullah Paşa'ya iki yazı yazıldı̆̆ 1 haber verilmiştir (A. MKT. 206/35 (1265. 7. 24)). 27 Haziran 1849'da Serasker ve Misır Paşa'sına da iki kıta yazı gönderilmiştir. Buna göre, Hicaz Havalisi’nde bulunan nizamiye askerlerinin ikmal edilmesi, eksikliklerin tamamlanarak bunlardan değiştirilmesi gereken askerlerin bir an önce değiştirilmesine dair ifadeleri içeren evrak Dar-1 Şura-yı Askeriye'den kaleme alınmıştır. Daha sonra Meclis-i Vala'ya verilip bu konuda tanzim edilen mazbatanın takdimini ve Meclis-i Umumi kararını içeren tezkere takımıyla gönderilmiş̧ir. Başıbozuk askerinin tertip ve istihdamına dair icap olduğu üzere Mısır ve Cidde Valileri paşalara tahrirat yazıldığı ve gerekenin yapılmasının istendiği belirtilmektedir. Özel bir memuriyetle Yemen tarafına gönderilmiş olan şerifin maiyetiyle Cidde'den nizami ve gayri nizami olarak yeterli miktar asker sevk olunmasıyla, gönderilecek askerlerin Cidde'ye varana kadar oraların hüsnü zabita ve muhafazası, 500 nefer başıbozuk askerinin vakitlice tertip ve istihdamına bağlıdır denmiştir. Şu kadar ki Hicaz Havalisi'nde başıbozuk askeri bulunmayıp Mısır tarafindan toplanması ve sevk edilmesi istenmektedir (A. MKT. MVL. 16/54 (1265. 8. 6)).

Yemen meselesinin çözümüne dair Cidde Valisi paşa tarafindan 1 Ağustos 1849 tarihli yazı bu sırada İstanbul'a ulaşmıştır (A. MKT. MHM. 16/18 (1265. 9. 12)). Aynı tarihte Cidde Defterdarı'na bir yazı da gönderilmiştir. Yazıda, Şerifin gayretiyle nizamiye askerlerinin Hudeyde İskelesi'ni alması ve Hudeyde Kalesi'nin ne suretle zapt olunduğuna dair tahrirat padişaha sunulmuştur. Padişah işbu Yemen meselesinde çözümüne dair memnuniyetini dile getirmiştir. Serasker Paşa'ya da gönderilen yazıda, Hudeyde Kalesi'nin zaptına dair Arabistan Ordusu tarafından gelen tezkere padişaha sunulmuştur (A. MKT. MHM. 16/18 (1265. 9. 12)).

Kıbrıslı Tevfik Paşa'nın gönderdiği bir rapor 3 Eylül 1849'da Cidde Valisi eliyle İstanbul'a ulaştırılmıştır. Giden haberlerde, San'a'da meydana gelen fesattan dolayı yapılan muharebeye dair durumu içeren rapor Hudeyde Kaymakamı Kıbrısı Tevfik Paşa tarafından gönderilmiştir. 
Zahire maddesine dair Şerif hazretleri tarafından birbirini takip eden müteakip yazılar gönderilmiştir. 10 Eylül 1849 tarihiyle takdim kılınan arizada dahi durum etraflıca sunulduğundan tekrarına girilmek istenmemiştir. Paşanın yazısında kendisi ve askerleri haylice sıkıntıya uğramışlardır. Araştırıldığına göre sıkıntı paşanın emirlere aykırı tavrından ve askerin zabıtasızlığından ileri gelmiştir. Ancak bu halde bırakılması caiz olamayacağından şerif hazretlerinin daha önce talep eylemiş olduğu 50.000 riyal ile yeterli miktardaki askerin süratle gönderilmesi istenmiştir. Bundan dolayı tüccardan bir miktar para tedarikiyle paranın, 400 nefer başıbozuk piyade askeriyle beraber Cidde'den gemiye yüklenmesine karar verilmiştir. Ancak bu sırada Mekke Şerifi Yemen'de girişilen harekâtı bırakarak Cidde'ye dönmüştür. Bu duruma bir anlam verilememişse de daha sonraki süreçte işlere bakmak üzere oğlu Abdullah Paşa Yemen'de bırakılmıştır (A. UM. 7/69 (1266. 1. 23)).

Tevfik Paşa, 2 Ekim 1849'da gelişmelerle ilgili bilgi vermiştir. Verdiği bilgilerde, Hazırmuş tarafına sefir tayin olunan Seyyid İshak Efendi şimdiye kadar Şerif Hüseyin, San’a İmamı maddeleriyle meşgul olup memuriyetine gidememiştir. Kendisine tahsis olunan 2.500 kuruş maaşla idare etmekte olup şerifin Mekke'ye avdetinde mecliste İshak Efendi, Hazırmuş için harcırah ve asker talebinde bulunmuştur. Ayrıca Hudeyde Hazinesi'nden bir miktar harcırah verilmesini istemiştir. Daha sonra San'a için talep olunan malum miktarda piyade askeri Hudeyde'ye gelince İshak Efendi'ye verilerek adı geçen mahale gönderilmiştir. Oraya varınca hiçbir şekilde muharebe etmemesi ise askeri yetersiz suretinde göstermiştir. İshak Efendi daha sonra yeterli miktarda mühimmat ve nizamiye askeri ile bir çarha top ile bazı gemiler talep etmiştir. Memuriyetini sefaret suretinde tutmayıp muharebe niyetinde görünmekte olduğundan bu şekilde tedariklice gönderilecek olursa, Aden tarafından gideceği ifade edilmiştir. Ancak Aden tarafından bu işe ne denileceği henüz belli olmadığından Hazırmuş tarafına vardığında ise muharebeye kalkışacağ 1 ve memuriyetini sefaret vazifesinden çıkardığ anlaşılmıştır. Kendisine bazı ihtarlarda bulunulsa da kendisinin niyetinin bu olduğu ve bu konuda 3-4 askerle bile gitmek gerektiği şeklinde bir teklifte bulunmuştur. Tevfik Paşa ise kendisine, Hüsnü Ağa'nın da geleceğini o geldiğinde gidebileceğini ifade etmiştir (A. MKT. 227/58 (1265. 11. 15)).

Tevfik Paşa, San'a'da olup biten ve yeni İmam Ali Mehdi hakkında Cidde Valisi Hasip Paşa'ya ayrıntılı bilgi vermiştir. Yemen Şerifi Hüseyin'in arapça şukkasından malum olacağ veçhile şimdiki San'a İmamı Ali Mehdi'nin, şerifi Yemen meselesine vasıta eylediği ve imam ile şerifin gönderdikleri yazılarda kabilelerin gözünün Tihame tarafında özellikle Hudeyde'de olduğu belirtilmektedir. İmamın bu şekilde devlete yakın durmasının nedeni ise o taraftaki ahalinin İmamın aleyhinde olmaya başlamasıdır. İmamın ise ahalinin ticaret için gidiş gelişlerine engel olmayacak şekilde bir bağlantı kurmaya çalıştığı Tevfik Paşa tarafindan ifade edilmektedir (A. MKT. 231/17 (1265. 12. 3)).

San’a'daki zabitlerin verdiği takrirlerden malum olacağı üzere San’a imamı akrabasıyla Hudeyde’ye gelip Seyyid Ahmed ile anlaşmışlardır. İane olarak ordu hazinesinden 25.000 frank ile Tevfik Paşa tarafından top ve asker talep etmiş̧ir. Oğlu ve kardeşinin bir müddet Hudeyde'de kalmasını istemiştir. San'a'ya bağlı birçok yer başka başka adamlar elinde olup imamın başka hiçbir şeyi yoktur. Yeterli asker olmadan, askerlerin tayını verilmeden girişilecek faaliyetlerin netice vermesi zordur. İngilizlerin bölgede etkin oldukları ve Tevfik Paşa'nın da San'a'daki hadiselerde yaralandığ 1 ifade edilmektedir (A. MKT. 231/17 (1265. 12. 3)).

Yemen'de memurların eski defterdardan aldıkları rahatlık ile San'a meselesinden dolayı göz önünde olmamalarından Hudeyde'de bazı irtikâp hadiseleri yaşanmıştır. Bu yüzden Hudeyde Mal Müdürünün değiştirilmesi gerekmektedir. Mal müdürünü kontrol etmek için birkaç adam gönderilmiş ve kendisine istediği şekilde hareket edemeyeceği gösterilmek istenmiştir. Güm- 
rüğe nezaret ettiği zamanda da herhangi bir sıkıntı olursa sorumlu olacağı da kayıt altına alınmıştır (A. MKT. 231/17 (1265. 12. 3)).

Hudeyde Mal Müdürü’nün sabık Cidde valisi Hasip Paşa'ya yazdığ ş̧ukkalardan anlaşıldığına göre, San'a imamı'nın Hudeyde'ye gelmesinden ve kendisine ziyade iltifat olarak mir-i miranlık nişanı verilmesinden dolayı rütbesine uygun mücevher kabzalı bir kılıç dahi verilmesini şerifin münasip görmesiyle Tevfik Paşa Ordu Hazinesi'nden 15.000 kuruş alarak kılıcını satmış ve imama vermiştir. Tevfik Paşa'nın imamla daha sonra olan muharebesi nedeniyle adı geçen mir-i miranlık ve oğullarına verilen iki kıta nişanlar alındığı gibi adı geçen kılıcı Tevfik Paşa almıştır. Ancak Tevfik Paşa, kılıcı hazineye vermemiştir. Adı geçen imam daha önce belirtildiği gibi Hudeyde'ye geldiğinde atiyye adıyla verilen 25.000 franktan bir miktarını dahi paşanın, Hudeyde'ye geldiğinde imamla aldığının söylenmesi üzerine durumun araştırılacağını söylemiştir (A. MKT. 231/17 (1265. 12. 3)).

Gelişmeler bu şekilde olurken bir süre sonra Tevfik Paşa'nın memuriyetiyle ilgili olumsuz ifadeler içeren yazılar görülmeye başlanmıştır. 25 Kasım 1849'da Cidde Valisi mühürlü bir yazıda, daha önce Şerif hazretleri marifetiyle Yemen'e memur ve tayin olunan bir tabur nizamiye askerinin bu kere çağırılmasında bir mahsur görülmemiştir. Yapılan tahkikat ve rivayetlere göre Hudeyde Kaymakamı Tevfik Paşa'nın sapmış olduğu irtikâp maddesine dair yazılan beş sual üzerine şerif tarafından cevap verilmiştir. Gelen cevaplar yetkili makama sunulmuş ve durumdan anlaşıldığına göre askerler oranın havası ve suyuna alışamadıklarından boş yere sıkıntı çekmektedirler. Bu yüzden bu tarafa getirilmeleri gerekirse de o tarafta yeterli asker olmadığından adı geçen askerlerin yerine bir miktar başıbozuk askeri sevkine ihtiyaç vardır. Birçok kere yazıldığı üzere Hicaz'da askerin az olmasından dolayı ne şekilde zaruret ve meşakkat çekilmekte olduğunu tarif etmeye gerek yoktur. Durum üzerine geçenlerde bir miktar başıbozuk askerinin süratle gönderilmesine müsaade buyurulmuştur. Tevfik Paşa hakkındaki mevzuda ise ne şekilde emir verilirse o şekilde yapılacağı bildirilmiştir (MVL. 230/71 (1266. M. 9)).

Bu sırada yaşanan bir gelişme de eski San’a İmamı Muhammed bin Yahya'nın öldürülmesi olmuştur. Şerif Hüseyin'in hazinedarının bazı Luhayya tüccarlarına yazdıklarına nazaran muharrem ayının 23. pazar gecesi San'a İmamı Ali Mehdi, sabık San'a İmamı Muhammed bin Yahya'nın başını kesmiş ve taşrada San'a İmamları neslinden Seyyid Ahmed ibn Haşim bir takım Arap askeri toplayarak İmam Ali'nin üzerine yürümüştür. San'a dışında kuvvetli bir muharebeden sonra İmam Ali bozulmuş ve imamın San'a'ya döndüğü ifade edilmiştir (MVL. 231/39 (1266. M. 29)).

Yemen'de işlerin bir türlü yoluna konulamadığ 1 sırada bu defa Kıbrıslı Tevfik Paşa'nın vefatı haberi gelmiştir. 8 Mart 1850'de Cidde Valisi Hasib Paşa'dan gelen bir yazıda, Tevfik Paşa'nın vefatı daha önce hususi bir şekilde Zeydiye muhafızları tarafından haber verilmiştir. Bundan dolayı derhal ferik paşa geçici bir memuriyete tayinle durumu araştırmak üzere gönderilmiş ve hadise hakkında detaylı bilgi sahibi olunmuştur. Buna göre Hudeyde Nizamiye Kaymakamı Ali Bey'den başka büyük zabit ve söz anlar kimse olmadığından kaymakam, mal müdürü, tüccarlar ve giden görevliden öğrenildiğine göre Süleyman Ağa Kaymakam Vekili tayin edilmiştir. Ağa muhafazaya dikkat etmekle görevlendirilmiştir. Velhiye Gümrükçüsü olup Mekke'de bulunan Abdülkadir Bey'e gönderilen tahriratta Şerif Hüseyin'in vefatı haberi de yazılmıştır. Gerçi tek bir rivayet varsa da hastalığı bir müddetten beri işitilmiş olmasıyla vefatı gerçekmiş gibi kabul edilip her türlü tedbirin alınması ve yerine uygun birinin atanması gündeme gelmiştir. Şerifin biraderlerinden Şerif Ali Hamud devletin taraftarı olduğu ve iyi hizmetleri görüldüğü Seyyid İshak Efendi taraflarından tahkik olunmuş olmasıyla adı geçenin veya başka birinin tayin edilmesi ferike havale edilmiştir. Bu nedenle giden ferike buyurulduğu 
açık bir şekilde ve icabına göre kardeşlerine verilmek üzere Arapça ibareli ve kendisine talimat ve senet olacak şekilde Türkçe ibareli iki kıta tahrirat verilmiştir. Eğer durum gerçek değilse bunu çok gizli tutması ve dikkat etmesi kendisinden istenmiştir. Şerifin diğer kardeşleri olan Şerif Hasan ve Şerif Haydar gayet uygunsuz adamlar olup kendilerinden emin olunması için bu tarafa gönderilmeleri dahi istenmiştir. Bu şekilde bölgeye gönderilen ferike haber ve talimatlar verilerek görevlendirilmiştir (A. MKT. UM. 12/26 (1266. 5. 23)).

12 Mart 1850'de Kaymakam Mehmed Ali'den gelen bir yazıda Tevfik Paşa'nın vefatı haberi daha ayrıntılı olarak açıklanmıştır. Buna göre, Hudeyde Kaymakamı Tevfik Paşa, Beni Kays Kabilesi tarafina bazı işleri çözmek için gidip, işlerini bitirip, tekrar Hudeyde'ye dönüşü esnasında Hudeyde'ye bir gün kala durumu bozulmuş ve o hal üzere 11 gün safralı hastalığ ile yatıp ardından vefat etmiştir. 1266 senesi rebiülahir ayının 27. pazar günü saat bir buçuk sularında ömrü son bulmuştur (Ahmet Raşit Paşa, bu vefatın 18 Rebiülahir 1266 Pazar günü gerçekleştiğini yazmaktadır. Bk. Ahmet Raşit Paşa 2013, 163) Tevfik Paşa'nın yerine geçici olarak görevlendirilen Süleyman Ağa: "icap eden bütün yerlere ve karakollara ve ahalinin istirahatı için dikkat etmelerini söyledim. Evvelkinden ziyade hıyanet ve sorun çıkabileceği beyan edilerek bütün çarşı ve sokaklarda dellallar çağırıp herkesin sükûnet içinde olmalarına mecbur olduklarını söylettim. Durum üzerine Moha Kaymakamı Abdullah Paşa ile diğer icap eden memurlara bildirilmiş olduğu üzere ve hatırı kalmaması için tüm ulema ve tüccarlar hazır bulundukları sırada vekil olduğum bildirildi" şeklinde İstanbul'a haber göndermiştir (A. MKT. UM. 12/26 (1266. 5. 23)). Yine 12 Mart 1850'de Tevfik Paşa'nın vefatı haberi, Hudeyde tarafından süvari başı Kadı Bayram kullarından gelen şukka ile haber alınmıştır. Bölgeden gelen yazılarda o tarafların idaresi önemli olduğundan 10 güne kadar kim uygun görülürse bu tarafa bildirilmesi istenmiştir (A. MKT. UM. 10/58 (1266. 4. 27)).

14 Mart 1850'de Esseyyid Osman tarafindan bir haber daha gönderilmiştir. Burada bazı tüccarlar Şerif Hüseyin vefat etti deyince bir miktar Arap çıkıp muharebe etmişler bir iki deveci yaralanmıştır. Merhum Tevfik Paşa'nın vefatı günü sabah Cihadiye Kaymakamı hazır olup gerekli kişilerle birlikte bazı eşyalarını mühürlemiş ve askerlerin bulunduğu karakollar tanzim edilmiştir. Hazinedar Mehmed Osman adı geçen kaymakamın üzerini teftiş etmiş ve üzerinde olanları kayıt altına almıştır (A. MKT. UM. 12/26 (1266. 5. 23)).

Kıbrıslı Tevfik Paşa'nın vefatı haberinin gelmesinden sonra 30 Mart 1850'de Mahmud Paşa'ya bir haber gönderilmiştir. Buna göre, Yemen'de eşrafin ve arabın işlerini görmek üzere nasp edilmiş Şerif Hüseyin vefat etti denmiştir. Emaretin henüz bir şerif üzerine ihalesi ve maaş tahsisi hakkında irade gelmemiştir. Yemen'de işleri görmek üzere birisinin emir nasp ve tayin olunması lazımedendir. Eyalette Şerif Ali Hamud'un devlete sadık birisi olduğu haber verilmiş ise de gerek o gerekse de daha münasip başka birisi olursa onun eyalete tayini lazım gelecektir şeklinde beyan olunmuştur. İsmi açık olmak üzere yazılan Arapça bir kıta buyuruldu dahi kendilerine gönderilmiş olup gerektiği gibi davranılması istenilmiştir. Ancak şerifin uzun süre hükümdarlığında ziyadece maaş ve tayınat verilmişse de bu defa tayin olunacak kişi şerif rütbesinde bulunacağından kendisine aylık 400-500 riyal kadar maaş tahsis olunması kararlaştırılmıştır. Vefat eden şerifin diğer biraderlerinden olup pek de emin kimseler olmadığı haber verilen Şerif Hasan ve Şerif Haydar'ın bir şekilde bu tarafa gönderilmeleri istenmiştir. Adı geçenlerden hangisi münasip ise onun emir nasp edileceği şeklinde icabı takdirinde kendilere verilmek üzere Arapça mektuplar dahi gönderilmiştir. Bunun yanında Ebu Ariş'in zekât gelirlerinin tahsilinde kendilerine yardımcı olmaları istenmiştir. İleride sıkıntı olmaması için eşraftan bazı kimselere 200-300 riyal kadar maaş verilmesinin de istendiği belirtilmektedir. Bunun içinde Seyyid İshak Efendi ile görüşülmesi ve müzakere edilmesi tavsiye edilmiştir (A. 
MKT. UM. 12/26 (1266. 5. 23)). Yemen meselesinin halledilememiş olması ve sahil ile adaların savunması gibi son derece önem arz eden bir duruma gelince 5 Nisan 1850'de Mekke Emiri Şerif Ali Paşa ve Abdullah Paşa'ya verilen gemilerle bu konuda uyanık durmaları istenmiştir (A. MKT. UM. 12/22 (1266. Ca. 22)); A. MKT. UM. 12/26 (1266. 5. 23)). Gönderilen gemilerle 500 kişilik bir Osmanlı birliği Moha'dan denize açılmış ve Güneybatı Yemen'deki önemli merkezler olan Şihr ve Mukalla'yı almak için harekete geçmiştir. Ancak Muhammed Habib komutasındaki yerel direniş Osmanlıların başarılı olmasına engel olmuştur. Bir başka Osmanlı birliği de Cebel Raymah'ın alınmasında başarı sağlayamamıştır (Baldry 1976, 165).

Kıbrıslı Tevfik Paşa'nın vefatının ardından üzerindeki rütbe ve nişanların durumu da mevzu olmuştur. 9 Temmuz 1851'de Meclis-i Vala'dan Kamil Paşa'nın nişanıyla Mekke Muavini Kıbrıslı Tevfik Paşa'nın mir-i miranlık nişanlarının alınarak maliyeye gönderilmesi ve kaydedilmesi istenmiştir (A. TŞF. 9/95 (1267. 9. 10)). Aynı konu üzerine 6 Ağustos 1851 tarihli bir

belgeyle de Meclis-i Vala azasından Kamil Paşa'ya vükelalık nişanı ihsan olunduğundan kendisinde bulunan Rumeli Beylerbeyliği payesi nişanıyla Mekke Muavini merhum Kıbrıslı Tevfik Paşa'nın mir-i miranlık nişanı maliyeye istenmiştir. Maliye Hazinesi yetersiz olduğundan bu nişanların alınmaları gerekli görülerek Dâhiliye Kâtibi'ne haber verilmiştir (A. MKT. NZD. 39/98 (1267. 10. 8)).

Tevfik Paşa'nın ölümünden Hicaz Valiliği, Fırka-i Askeriye Kumandanı Mahmud Paşa'yı, Hudeyde Vali Vekâleti'ne gönderdi. Kısa bir süre sonra da Mustafa Sabri Paşa Yemen Valiliği'ne atandı (Sırma 2008, 53-55). Mustafa Sabri Paşa, 1851'de ansızın ölünce Mehmed Sırrı Paşa, müteakiben o da valilikten alınarak yerine 1862'de Bonapart Mustafa Paşa gönderildi. Tedbirsiz hareket eden bu paşa kuvvetleriyle birlikte Araplar tarafından pusuya düşürüldü ve kaçarken yolda öldü. Nihayet Ahmed Muhtar Paşa son olarak San'a'yı da alıp Yemen'in fethini tamamladi (Sirma 1997, 377).

\section{Sonuç}

Yemen, Osmanlı Devleti için 19. yüzyılda oldukça önem atfedilen bir arazi olmuştur. Bu önem sadece arazinin kendisi üzerinden değil, son derece stratejik bir nokta üzerinde oluşundan da kaynaklanmıştır. Osmanlı Devleti'nin bu bölgede tekrar bir hâkimiyet kurmak istemesinde bu durum önemli bir rol oynamıştır. Öyle ki bazı yazışmalarda İngilizlerin Aden'e yerleştikleri ve bu durumun bölge için son derece nazik bir vaziyet ortaya koyduğu ifade edilmektedir. Aden'e yerleşen İngilizlerin burada rahat durmayacakları ve Osmanlı Devleti'ne ait başka topraklara da buradan hareketle müdahale edebilecekleri veya karışıklık çıkarmak isteyebilecekleri endişesi rahatlıkla belgelerde görülebilmektedir.

Yemen üzerinde sadece İngilizler ve başka güçlerin egemen olacağ endişesi yanında özellikle Asir diye ifade edilen bölgedeki kabilelerin Yemen'de ve Hicaz topraklarında kargaşaya neden olabilecekleri kaygısı da Osmanlı Devleti'ni aktif hale getirmiştir. Özellikle Tihame adıyla adlandırılan bölge üzerinde Asirlilerin ve San'a'daki İmamların nüfuz kurmak istemelerine karşı buranın elde tutulması için yoğun bir gayret sarf edildiği ifade edilmektedir. Bir ara Asir kabilelerinin başında olan Aid bin Meri'nin Tihame taraflarına sarkmak istemesi de mevcut endişeleri ilerisi için daha da arttırmıştır. Bu bölgenin elde tutulabilmesi için de Kıbrıslı Tevfik Paşa'nın İstanbul'a gönderdiği ve padişahın da dikkatini çeken layihası önemli bir rol oynamıştır.

Yazışmalarda ve olayın gelişimi sırasındaki hadiselere bakıldığında Osmanlı Devleti’nin bölgeye son derece önem vermesine karşın bu bölgede etkin bir otorite kuracak kadrodan yoksun olduğu gözlenmektedir. Osmanlı Devleti'nin Hicaz ve Hudeyde gibi bölgelerdeki idari memurları kadar İstanbul gibi başkentindeki birçok yönetici de açıklamalarında bunu ifade 
etmekten geri kalmamışlardır. Bu kadro eksikliğinden dolayı bölge bir ara kabile liderleri ve şerifler aracıllğı ile yönetilmeye çalışılmıştır. Ne var ki bu isimlerin de bölgeyi iyi bir şekilde idare edemedikleri ortadadır. Birçok defa ifade edildiği üzere Yemen'in gelirlerinin harcamalarına yetmediği ve asayişle ilgili birçok sorunun sık sık yaşandığı gözlenmektedir. Yemen'in en önemli gelirlerinden olan limanlarla ilgili de tam bir düzenin olmadığı bunun yanında bölgede söz sahibi olmak isteyen isimlerin hem idari hem de ekonomik açıdan bu noktalara özel önem verdikleri dikkati çekmektedir. Buna rağmen gümrüklerle ilgili birtakım usulsüzlüklerin yapıldığı ve bunda bölgenin üst düzey idarecilerinin de parmağı olduğu görülmektedir.

Kıbrıslı Tevfik Paşa'nın Yemen'in alınması gündeme geldiğinde bölgede dikkat çeken isimlerden biri olduğu hemen fark edilmektedir. Yazışmalarından ve kendisi ile ilgili sık sık övücü sözler söylenmesinden bu durum anlaşılmaktadır. İstanbul'a gittiğinde götürdüğü hediyelerden dolayı ön planda olmayı kendisinin de arzuladığını söylemek mümkündür. Kıbrıslı Tevfik Paşa elindeki imkânları iyi bir şekilde kullanarak Yemen'in alınmasında önemli bir rol oynayacak noktaya ulaşmıştır. Ancak askeri açıdan yetersiz olması ve Yemen'e ulaştığında bölgenin yapısını iyi kavrayamamasının etkisiyle yürüttüğü faaliyetlerden pek netice alınamamıştır. Hudeyde gibi şehirlerin alınması kolay bir şekilde gerçekleşmişse de San'a'nın alınması için yaptığı teşebbüsteki hareket tarzı bunu göstermektedir. San'a'da birçok Osmanlı askerinin hayatını kaybetmesi ve kendisinin de yaralanması tedbirsizliğine bir örnek olarak gösterilmektedir. Hudeyde'yi almasından sonra davranışlarında görülen hakimane tavır ve yerel güçleri arka plana alışı başarısızlığının bir başka nedeni olmuş gibi gözükmektedir.

Osmanlı Devleti, Yemen'in ve özellikle San'a'daki İmam'ın kontrol altına alınmasını Arap Yarımadası ve Kızıldeniz için gerekli gördüğünden Kıbrıslı Tevfik Paşa ile başlayan askeri ve idari hareketlilik onun ölümünden sonra da devam ettirilmiştir. Bu tarihlerde başlayan teşebbüs 1911'de varılan anlaşmaya kadar sürekli bir çatışma ortamı yaratmışsa da Yemen'e gösterilen ilgi artarak devam etmiştir. Yemen'de Kıbrıslı Tevfik Paşa'nın gayretleri ile başlayan girişimin başarıyla sonuçlanmamasında Osmanlı Devleti'nin henüz kendini toparlayamamış olmasının da önemli bir rolü olmuşa benzemektedir. Her ne kadar Avrupa'daki ihtilal hareketleri buradaki askeri faaliyetlere yabancı müdahalesini azaltmış gibi gözükse de Osmanlı Devleti'nin Tanzimat süreci, Mehmed Ali Paşa ve İbrahim Paşa'nın ölümlerinden sonra bölgedeki mevcut durumun henüz yerine oturmamış olması da Yemen'de Osmanlı otoritesinin hemen gerçekleştirilememesine etki etmiş gibi durmaktadır. Yine de tüm olumsuzluklarına rağmen Osmanlı Devleti'nin kendi yazışmalarında da belirttiği gibi temel gayesinin vergi toplamak veya görünüşte bir otorite tesis etmekten ziyade Yemen'de düzeni sağlamaya dönük olduğu açıkça anlaşılmaktadır. 


\section{KAYNAKÇA}

\section{Araştırma ve İnceleme Eserler}

Ahmet Raşit Paşa (2013). Tarih-i Yemen ve San’a, I-II. Yay. Haz. Sadettin Baştürk, Ankara 2013.

Akalın D. (2014). “Aden'in İşgali ve İşgalden Sonra Osmanlı Devleti’nin Kızıldeniz'de Aldığı Bazı Tedbirler”. Tarih Incelemeleri Dergisi XXIX/2 (2014) 357-404. Ankara.

Akalın D. (2014). “İngiltere ve Osmanlı Devleti Arasında Perim Adası (1798-1914)”. Tarih Araştırmaları Dergisi 33/56 (2014) 233-263. İzmir.

Akalın D. \& Parlaz S. (2010). “Nil’de İktidar Mücadelesi ve Kavalalı”. Çankırı, Avrasya Strateji Dergisi Cilt 1/1 (2010) 115-134.

Arendonk C. V. (1997). “Şerif Maddesi”. İslam Ansiklopedisi 11 (1997) 435-442. Eskişehir.

Armaoğlu F. (1999). 19. Yüzyll Siyasi Tarihi (1789-1914). Ankara 1999.

Baldry J. (1976). “Al-Yaman and the Turkish Occupation 1849-1914”. Arabica, T. 23, Fasc. 2, Brill.

Darkot B. (1997). “Asir Maddesi”. İslam Ansiklopedisi 1 (1997) 674-675. Eskişehir.

Darkot B. (1997). “Hudeyde Maddesi”. Isslam Ansiklopedisi, 5/1 (1997) 579-581. Eskişehir.

Gencer A. İ. (2001). Bahriye'de Yapılan Islahat Hareketleri ve Bahriye Nezareti’nin Kuruluşu (17891867). Ankara 2001.

Karal E. Z. (1999). Osmanlı Tarihi, V. Ankara 1999.

Kızıltoprak S. (2010). Mısır'da İngiliz İşgali Osmanlı 'nın Diplomasi Savaşı (1882-1887). İstanbul 2010.

Orhonlu C. (1996). Osmanlı Imparatorluğu'nun Güney Siyaseti Habeş Eyaleti. Ankara 1996.

Pakalın M. Z. (1993). Osmanlı Tarih Deyimleri ve Terimleri Sözlüğ̈̈ II, I-II. İstanbul 1993.

Sırma İ. S. (2008). Osmanlı Devleti’nin Yıkılışında Yemen İsyanları. İstanbul 2008.

Sırma İ. S. (1997). “Yemen Maddesi”. İslam Ansiklopedisi 13 (1997) 373-384. Eskişehir.

Yeşilyurt Y. (2011). Yemen'de Osmanll-İngiliz Mücadelesi 1871-1914. Yayınlanmamış Doktora Tezi. Atatürk Üniversitesi, Sosyal Bilimler Enstitüsü, Tarih Anabilim Dalı 2011.

\section{Arşiv Belgeleri}

A. DVN. 23/34 (1263. 3. 16); 35/43 (1264. 1. 29).

A. MKT. 70/96 (1263. 3. 25); 93/15 (1263. 9. 3); 94/85 (1263. 10. 3); 127/35 (1264. 6. 7); 134/66 (1264. 7. 15); 135/1 (1264. 7. 15); 135/14 (1264. 7. 16); 135/75 (1264. 7. 20); 136/56 (1264. 7. 26); $136 / 96$ (1264. 7. 28); $137 / 77$ (1264. 8. 4); 138/18 (1264. 8. 8); 157/47 (1264. 12. 3); 157/52 (1264. 12. 4); 160/28 (1264); 160/38 (1264); 160/51 (1264); 171/60 (1265. 3. 5); 206/35 (1265. 7. 24); 216/15 (1265. 9. 7); 227/58 (1265. 11. 15); 227/76 (1265. 11. 15); 231/17 (1265. 12. 3); 236/54 (1265).

A. MKT. MHM. $2 / 66$ (1263. 8. 9); 2/73 (1263. 9. 27); 7/22 (1264. 12. 2); 16/18 (1265. 9. 12); 116/65 (1274. M. 14)

A. MKT. MVL. 16/54 (1265. 8. 6).

A. MKT. NZD. 39/98 (1267. 10. 8).

A. MKT. UM. 10/58 (1266. 4. 27); 12/26 (1266. 5. 23).

A. TŞF. 9/95 (1267. 9. 10).

A. UM. $7 / 69$ (1266. 1. 23).

İ. DH. 138/7089; 170/9031

İ. MMS. 15/320 (1264. Ca. 7); 63/1810 (1264. S. 25); 63/1811 (1264); 63/1815 (1264. C. 5); 63/1821 (1264. N. 20).

HR. MKT. 18/55 (1263 N. 27).

MVL. 230/71 (1266. M. 9). 